\title{
La potestad sancionadora de la Administración en el ámbito de los bienes públicos
}

\author{
Dionisio Fernández de Gatta Sánchez
}

Sumario: I. INTRODUCCIÓN. II. LA TRASCENDENCIA DE LOS BIENES PÚBLICOS COMO JUSTIFICACIÓN DE SU REGULACIÓN Y PROTECCIÓN. 1. Aspectos históricos de los bienes públicos y de su protección. 2 . El régimen jurídico actual de los bienes públicos y sus clases: bienes de dominio público o demaniales y bienes patrimoniales. III. EL SISTEMA DE PROTECCIÓN DE LOS BIENES PÚBLICOS. 1. Referencias generales.2. Medios de protección. A) Limitaciones a la disponibilidad de los bienes. B) Publicidad posesoria y régimen registral. C) Facultad de investigación. D) Deslinde. E) Facultad de recuperación posesoria. F) Desahucio administrativo. G) Potestad de policía demonial. H) Protección penal de los bienes públicos. IV. LA POTESTAD SANCIONADORA DE LA ADMINISTRACIÓN EN MATERIA DE BIENES PÚBLICOS. 1. Aspectos históricos de la potestad sancionadora de las administraciones públicas en materia de bienes públicos. 2 . El régimen jurídico general en materia sancionadora. 3. El sistema normativo de la potestad sancionadora en materia de bienes públicos. 4. El régimen de la potestad sancionadora en la Ley de Patrimonio de las Administraciones Públicas. A) La aplicación de los principios rectores, y del régimen general, del ámbito sancionador por la ley de patrimonio de las administraciones públicas y por la legislación sectorial sobre bienes concretos. a) Principios de legalidad y de tipicidad. b) Principio non bis in idem. c) Principio de culpabilidad. d) Otros principios aplicables. B) Aspectos procedimentales. 5. El problema del carácter de la extinción de las autorizaciones y concesiones demaniales. A) Aspectos generales sobre el uso de los bienes demaniales, las autorizaciones y las concesiones. B) La naturaleza de la extinción de las autorizaciones y concesiones demaniales.

\section{INTRODUCCIÓN}

Las heterogéneas funciones encomendadas a las Administraciones Públicas por la Constitución Española y el resto del sistema normativo, incluyendo el Derecho de

1 Profesor Titular de Derecho Administrativo. Universidad de Salamanca. 
la Unión Europea, pueden llevarse a cabo de muchas y variadas formas. Habitualmen$t^{2}$, desde la perspectiva de la actividad administrativa se suelen mencionar la actividad de policía o de limitación, las actuaciones de fomento o estimulantes, la relativa a la prestación de servicios públicos y la actividad de gestión económica; si bien en la actualidad, cada una de las anteriores se ha diversificado y se han hecho más complejas (en parte debido a la propia complejidad de la sociedad de nuestros días). Además, también deben recordarse otras relacionadas estrechamente con las anteriores, como la potestad normativa (principalmente, la reglamentaria) o la potestad de planificación, que se utilizan habitualmente.

En el desempeño de las actividades anteriores, las Administraciones Públicas ejercitan potestades administrativas, es decir, poderes jurídicos reconocidos por el sistema normativo, y susceptibles de ser ejercitados por las mismas; potestades que habitualmente se reconocen de modo genérico, siendo necesario que se produzcan determinadas circunstancias para su concreción o que existan necesidades de interés general que precisen lo mismo. Por otra parte, estos modos de actuación de las Administraciones Públicas son ámbitos de su propia responsabilidad, cuya plasmación y cumplimiento prevé el Ordenamiento Jurídico. Finalmente, debe destacarse que estos medios de actuación administrativa son compatibles entre sí, siendo todos utilizados habitual e indistintamente en los diversos sectores materiales.

Brevemente, en relación con tales formas de actuación administrativa, podemos señalar que la actividad de policía o de limitación supone que las Administraciones Públicas, en el ejercicio de las funciones previstas en el Ordenamiento Jurídico, intervienen e inciden en las actividades de los ciudadanos condicionando o limitando el ejercicio de sus derechos subjetivos o intereses legítimos, por razones de interés general. Las actividades de policía más visibles y habituales son las relativas a la protección de la seguridad pública y la potestad sancionadora, pero, como es bien sabido, no son las únicas pues existen otras formas de intervención en el ámbito privado menos perturbadoras para los derechos e intereses de los ciudadanos. Entre éstas se encuentran, como fórmula típica del Derecho Administrativo, las autorizaciones, las licencias o los permisos, que sirven de condicionante para el ejercicio de derechos o la consolidación de intereses de los ciudadanos y de las empresas previstos en la normativa vigente, permitiendo contrastar la actividad concreta con el sistema normativo correspondiente, o las acciones de inspección, para determinar el cumplimiento

2 Sobre la base del conocido esquema clásico de Jordana de Pozas, L., "Ensayo de una teoría de fomento en el Derecho administrativo", Revista de Estudios Políticos, n. 48/1949, pp. 41 y ss., seguimos a Bermejo Vera, J. en la obra dirigida por él mismo, “Derecho Administrativo. Parte Especial”, 6. a Ed. Civitas, Madrid, 2005, pp. 49-73. En general, vid. De la Cuétara, J. M., "La actividad de la Administración”, Ed. Tecnos, Madrid, 1983, y Santamaría Pastor, J. A., “Principios de Derecho Administrativo General”, Tomo II, Ed. Iustel, Madrid, 2004, pp. 237-241. Desde otro punto de vista, ver Fernández de Gatta Sánchez, D., “Establecimientos y alojamientos turísticos, territorio y medio ambiente: el régimen jurídico-administrativo de la Comunidad de Castilla y León”, en Alves Correia, F., y Bassols Coma, M. (Coord.), y otros, “I Jornadas LusoEspañolas de Urbanismo. Actas” [Jornadas celebradas en el Auditorio de la Facultad de Derecho de la 450 Universidad de Coimbra los días 9 y 10 de octubre de 2008], Ed. Almedina, Coimbra (Portugal), 2009,
pp. 238-241. 
del sistema normativo por los ciudadanos y las sociedad en general, y en su caso el ejercicio de la potestad sancionadora, en casos de incumplimiento del Ordenamiento o de los mandatos y actos administrativos. Además, deben destacarse en este mismo ámbito las prohibiciones y mandatos administrativos o la imposición de requisitos a cumplir por los agentes implicados.

En segundo lugar, la actividad administrativa de fomento supone el ofrecimiento de estímulos positivos a los ciudadanos y a las empresas para conseguir, o contribuir a ello, determinados fines, fijados en el Ordenamiento de acuerdo con el interés general; es decir, mediante el mismo la Administración dirige la actividad concreta por los cauces y hacia los fines deseados por la misma. Las medidas de fomento son variadas, si bien las más habituales son las de carácter honorífico, jurídico, y particularmente las de carácter económico-financiero.

A continuación, la actividad administrativa prestacional o de servicio público, mediante la que las Administraciones Públicas prestan o ejercen determinados servicios y funciones para los ciudadanos que se consideran esenciales o importantes para la sociedad; prestándose ésos servicios o ejercitándose estas funciones de forma obligatoria, regular y con continuidad. Ahora bien, los servicios públicos no pueden concebirse de una forma estática pues se van ampliando con el paso del tiempo a aquellas actividades económicas que adquieren tal condición, como consecuencia de transformaciones técnicas, sociales o económicas.

En este breve repaso, por último, la actividad económica directa supone el ejercicio, por parte de las Administraciones Públicas, de una actividad de producción de bienes o de prestación de servicios de carácter económico; destacando las actividades comerciales e industriales. Esta actividad se reconoce directamente en el artículo 128 de la Constitución Española.

Por otra parte, las Administraciones Públicas, como cualquier otra persona jurídica, pública o privada, necesitan de un conjunto de bienes y derechos, que constituyen su patrimonio, para el cumplimiento de sus fines y para la satisfacción de sus necesidades, tal como señala con claridad la STC 166/1998, de 15 de julio, al precisar que "las Administraciones Públicas han de contar con bienes de distinta naturaleza para el cumplimiento de sus diversas funciones” (FJ n. ${ }^{\circ} 11$ ). En efecto, la Administración Pública, con capacidad plena para el ejercicio de sus funciones y cumplimiento de los fines públicos y competencias atribuidos por el Ordenamiento Jurídico, así como para el despliegue de las potestades señaladas, precisa contar con instrumentos y medios personales, materiales, económico-financieros y jurídicos; destacando entre estos los bienes y derechos que constituyen su propio patrimonio ${ }^{3}$. Además, deben tenerse en

3 Moreu Carbonell, E., “El Derecho Público de los Bienes”, en Bermejo Vera, J. (Dir.), y otros, “Derecho Administrativo. Parte Especial”, 6. ${ }^{a}$ ed., Ed. Thomson-Civitas, Cizur Menor (Navarra), 2005, p. 331. También, en relación con los bienes de las Administraciones Locales, ver Fernández de Gatta Sánchez, D., y Pérez Alecart, A., “Manual del Alcalde”, 2. ${ }^{\text {a }}$ ed. ampliada, Ed. Diputación de Valladolid-Universidad de Salamanca, Valladolid, 2004, p. 107. 
cuenta asimismo aquellos bienes cuyo uso redunda en beneficio para la sociedad, al asegurarse el mismo por los ciudadanos (p. ej., el agua o las costas). Así, en sentido integrador y completo, el art. 3-1. ${ }^{\circ}$ de la Ley 33/2003, de 3 de noviembre, del Patrimonio de las Administraciones Públicas (BOE del 4), señala que el mismo "está constituido por el conjunto de sus bienes y derechos, cualquiera que sea su naturaleza y el título de su adquisición o aquel en virtud del cual les hayan sido atribuidos", incluyendo con normalidad los bienes de dominio público y excluyéndose, según el art. 3-2. , el dinero, los valores, los créditos y los demás recursos financieros de su hacienda, constituyendo lo primero una novedad destacable y no entendiéndose completamente las exclusiones señaladas, dada su importancia ${ }^{4}$.

Teniendo en cuenta la trascendencia del patrimonio de las Administraciones Públicas 5 , tanto por facilitar el desarrollo de sus propias funciones como para permitir el uso del mismo por los ciudadanos, se hace necesaria su protección para garantizar su integridad y su destino a uno o varios fines públicos, tal como de forma novedosa prevé el art. 28-LPAP, al señalar que "las Administraciones Públicas están obligadas a proteger y defender su patrimonio", y añadir, de forma redundante, que "a tal fin, protegerán adecuadamente los bienes y derechos que lo integran”; desarrollándose detalladamente en el Título II (arts. 28 a 64) y en el Título IX (arts. 192-197)- LPAP6.

Estos instrumentos y técnicas de protección de los bienes públicos, que analizaremos más adelante, tienden a garantizar la propia titularidad pública de los mismos, su posesión y los fines públicos mencionados, incluyendo entre los mismos, tanto por la Legislación general como por la específica relativa a cada uno de los bienes, el régimen sancionador? . De acuerdo con la obligación general de protección, establecida

4 En relación con este precepto y su contenido, por todos, ver Menéndez García, P., “Ámbito objetivo de regulación y extensión del dominio público", en Mestre Delgado, J. F. (Dir.), y otros, “El Régimen Jurídico del Patrimonio de las Administraciones Públicas (Comentario a la Ley 33/2003, de 3 de noviembre)", Ed. El Consultor, Madrid, 2004, pp. 125-139; Uría Fernández, F., “Patrimonio de las Administraciones Públicas. Artículos 3 a 9”, en De Fuentes Bardajía, J. (Dir.), y otros-Abogacía General del Estado (Dirección General del Servicio Jurídico del Estado), “Comentarios a la Ley de Patrimonio de las Administraciones Públicas”, Ed. Abogacía General del Estado y Ed. Thomson-Aranzadi, Cizur Menor (Navarra), 2008, pp. 145-151, y Santamaría Pastor, J. A., “Objeto y ámbito. La tipología de los bienes públicos y el sistema de competencias”, en Chinchilla Marín, C. (Coord.), y otros, “Comentarios a la Ley 33/2003, del Patrimonio de las Administraciones Públicas”, Ed. Thomson-Civitas, Cizur Menor (Navarra), 2004, pp. 43-109.

5 En relación con el debate sobre los bienes públicos, ver Gaudemet, Y., "El futuro del Derecho de las propiedades públicas”, trad. por J. A. Carrillo Donaire, Revista Andaluza de Administración Pública, n. 40/2000, pp. 11-24.

6 Abajo Quintana, J. J., “De la obligación de proteger y defender el patrimonio. Arts. 28 a 31”, en De Fuentes Bardajía, J. (Dir.), y otros-Abogacía General del Estado, obra citada, pp. 391-397; Jiménez Plaza, C., "La obligación de protección y defensa del patrimonio de las Administraciones Públicas", en Mestre Delgado, J. F. (Dir.), y otros, obra citada, pp. 333-336, y Ballesteros Moffa, L. A., "Protección y defensa del patrimonio: obligación administrativa, cooperación y límites de disponibilidad”, en Chinchilla Marín, C. (Coord.), y otros, obra citada, pp. 202-211.

7 Moreu Carbonell, E., “El Derecho Público de los Bienes”, op. cit., pp. 347-348, y Lozano Cutanda, B., “Infracciones y sanciones para la protección de los Bienes Públicos”, en González García, J. V. (Dir.), y otros, “Diccionario de Obras Públicas y Bienes Públicos”, Ed. Iustel, Madrid, 2007, pp. 398-399, y “Régimen 
en el art. 28, la Ley de Patrimonio de las Administraciones Públicas, de forma novedosa, articula un régimen de protección común a todos los bienes que se integran en su ámbito, sin perjuicio de algunas peculiaridades, que reconoce, y regula con carácter general, la potestad sancionadora de la Administración (arts. 192 a 197); aunque en relación a su régimen jurídico ha de atenderse asimismo a la Legislación general sobre régimen jurídico y procedimiento administrativo común, a la relativa a las distintas Administraciones y a la normativa específica de los bienes públicos correspondientes.

\section{LA TRASCENDENCIA DE LOS BIENES PÚBLICOS COMO JUSTIFICACIÓN DE SU REGULACIÓN Y PROTECCIÓN}

La importancia de los bienes públicos en la sociedad actual, debido a las funciones que permiten desarrollar a las Administraciones Públicas y a las posibilidades de uso por los ciudadanos, ha evolucionado en la Historia hasta la actualidad, depurándose su definición y su propio régimen jurídico, articulándose su protección de forma adecuada y permitiendo ver las razones por las que tales bienes públicos se sujetan a un régimen jurídico diferente al aplicable a los de los particulares.

\section{Aspectos históricos de los bienes públicos y de su protección}

Será en el siglo XIX, como es sabido, primero en Francia, cuando surja el concepto del dominio público, tal como se entiende actualmente; aunque materialmente tales bienes públicos ya existían, e incluso tenían lo que podríamos llamar un régimen jurídico propio, distinto del aplicable a los bienes de los particulares, debido a sus peculiares funciones ${ }^{8}$, y se atendía a los posibles daños que se causaran a los mismos.

En el Derecho Romano ${ }^{9}$ ya se distinguían con claridad distintos tipos de bienes, con un régimen jurídico diferente. Así, además de los bienes privados, objeto de apropiación y comercio (res privatae), existían bienes públicos, debiendo mencionarse los consagrados a los dioses (res divini iuris, que se distinguían en función de la importancia de las divinidades, e incluían las puertas y los muros de las ciudades) y los bienes relativos a los hombres o de uso humano (res humani iuris), entre los que se incluían las res publicae, que pertenecían al pueblo romano como comunidad organizada, y

\footnotetext{
sancionador”, en Chinchilla Marín, C. (Coord.), y otros, “Comentarios a la Ley 33/2003, del Patrimonio de las Administraciones Públicas”, Ed. Thomson-Civitas, Cizur Menor (Navarra), 2004, pp. 889-891.

8 Serna Vallejo, M., “Los bienes públicos: formación de su régimen jurídico”, en González García,

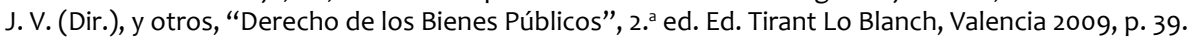

9 Sobre esta época, ver Parejo Alfonso, L., "Dominio Público: un ensayo de reconstrucción de su teoría general”, Revista de Administración Pública, n. 100-102/1983, pp. 2383-2387; Serna Vallejo, M., obra citada, pp. 39-41, y García-Manzano Jiménez de Andrade, P., “Antecedentes históricos”, en De Fuentes Bardajía, J. (Dir.), y otros-Abogacía General del Estado (Dirección General del Servicio Jurídico del Estado), “Comentarios a la Ley de Patrimonio de las Administraciones Públicas", Ed. Abogacía General del Estado y Ed. Thomson-Aranzadi, Cizur Menor (Navarra), 2008, pp. 87-88.
} 
que podían tener cierto uso público, siendo posible que los bienes se integraran en esta categoría por derecho de gentes en atención a su naturaleza (como el mar, las costas o los ríos) o porque fueran destinadas al uso público mediante un acto del poder público, como la publicatio (como las calles, los puentes, plazas y foros, etc.); los cuales ya gozaban de una apreciable protección pues estaban fuera del comercio. Junto a estos también se hacía referencia a aquellos bienes de garantizaban el sostenimiento de los gastos públicos, que podían ser objeto del comercio, y, lo que es más destacable, algún jurista se refiere las res communes omnium, incluyendo el aire, el agua, el mar y la costa, como bienes que pertenecen a todos, siendo posible su uso por cualquiera, pero con el límite de no impedir esta misma posibilidad a los demás, así como a las res nullius, que no pertenecían a nadie. Los romanos, pues, ya distinguían claramente los bienes privados y los públicos, sometían estos últimos a un régimen jurídico especial (articulado solemnemente mediante un acto del poder público como la dicatio ad populum o la publicatio, cuando ese uso no estuviese ya determinado por la naturaleza de los bienes), que se justifica precisamente en garantizar el destino al que se vincula el bien concreto.

Por otra parte, en el Derecho germánico ${ }^{10}$ surge una propiedad colectiva, común, cuya titularidad corresponde a todos los comuneros de forma indistinta.

Seguidamente, desde la Edad Media hasta el final del Antiguo Régimen (siglos XI a XVIII) ${ }^{11}$ seguirán utilizándose las categorías romanas, simplificándolas, pero con algunos cambios resaltables. Así, se diferencian las cosas comunes a todos los seres vivos, que no pueden ser objeto de apropiación (como los astros, el aire, el agua de lluvia, el mar y la costa), las cosas comunes a los hombres o cosas públicas (como los ríos, los puertos, los bosques, los pastos y los caminos) y las cosas comunes a las ciudades, unas de uso común por todos los vecinos (como los muros, las fuentes o las plazas) o otras destinadas a producir ingresos para sostener la propia comunidad, y que por ello están en el comercio. Distinción que se plasmará en Las Partidas del rey Alfonso X.

Posteriormente, cuando se fortalecen los Reinos cristianos, aparecerá la idea del patrimonio del Príncipe, del Rey o de la Corona (dominium principis), que se integraba por los bienes de carácter personal (que se adquirían mediante compra, por herencia o por conquista) y por aquellos otros que le pertenecen en tanto que Rey, los cuales están destinados al sostenimiento del Reino, por lo que son protegidos y administrados por el Monarca; e incluso se menciona también el patrimonio fiscal en el que se integraban las rentas públicas, parte de las cuales se asignaban al mismo para sus gastos; considerándose todos inalienables de acuerdo con Las Partidas y son protegidos por actuaciones concretas para limitar su transmisión (p. ej., de las Cortes de Al-

10 García-Manzano Jiménez de Andrade, P., obra citada, p. 88.

11 Serna Vallejo, M., obra citada, pp. 41-45; García-Manzano Jiménez de Andrade, P., obra citada, pp. 88-90; Parejo Alfonso, L., obra citada, pp. 2388-2391, y Muñoz Machado, S., “Dominio Público (Forma454 ción histórica y régimen jurídico)”, en González García, J. V. (Dir.), y otros, “Diccionario de Obras Públicas y Bienes Públicos", Ed. lustel, Madrid, 2007, pp. 335-346. 
calá en 1348 o de las Cortes de Valladolid en 1442) y para recuperar algunos (como el rey Alfonso IV en 1469 y 1487 o el rey Carlos II en 1674).

Más adelante, las categorías anteriores de cosas públicas se simplifican y se pasará a hablar únicamente de bienes de las ciudades o municipales y bienes de la Corona, ya que las cosas comunes a los seres vivos dejan de interesar a los juristas, incorporándose a los bienes de esta, y las cosas comunes a los hombres acabarán por integrarse también en este mismo patrimonio de la Corona. Además, debe resaltarse que en este mismo conjunto de bienes se irán distinguiendo varios títulos de atribución, con consecuencias jurídicas también diversas, destacando entre todos la regalía ${ }^{12}$, como derechos cuya titularidad se atribuye con exclusividad al Rey con la finalidad de proteger los intereses del reino, siendo posible que recayeran sobre potestades públicas (como juzgar o acuñar moneda) o sobre bienes (como aguas, bosques y montes, caminos o puentes), y también la cesión o arrendamiento de su ejercicio a los particulares; aplicándose a los mismo el régimen de las cosas públicas, pero personificando ya su titularidad.

Además, en esta época medieval pueden citarse las primeras normas municipales protectoras de los bienes públicos, incluyendo ya la imposición de multas y la obligación de reparación de los daños causados a los mismos. Asimismo, a finales del Antiguo Régimen comienzan a aprobarse normativas sectoriales en relación con bienes públicos concretos, incluyendo normas protectoras ${ }^{13}$.

Mucho más importante será la incidencia de la Revolución francesa en los bienes públicos y en su régimen jurídico, pues la misma provocará "también una revolución sobre el régimen jurídico de los bienes de la Corona" "14, ya que la Ley de 22 de noviembre-1 de diciembre de 1790 transfiere a la Nación (por su vinculación al concepto de soberanía) la titularidad de estos bienes (comenzando a hacer indistintos "dominio público" y "dominio nacional”) y, lo que es verdaderamente destacable, admite eliminar su tradicional régimen protector al suprimirse la prohibición de enajenar los bienes de la Corona, permitiendo pues su enajenación (teniendo en cuenta que el Decreto de 19 de diciembre de 1789 ya había previsto la venta del patrimonio de la

12 García-Manzano Jiménez de Andrade, P., obra citada, pp. 89-90, y Parejo Alfonso, L., obra citada, pp. $2389-2390$.

13 Font y Llovet, T., “La protección del dominio público en la formación del Derecho Administrativo Español: Potestad sancionadora y resarcimiento de daños", Revista de Administración Pública, n. 123/1990, pp. 8-24, cita el Fuero de Coria, la ordenación local de Tortosa de 1344 y los Fueros de Aragón, así como las normativas sobre montes públicos, caminos, puentes y riegos, como ejemplos [Este trabajo también está publicado en Varios Autores, "Actualidad y perspectivas del Derecho Público a fines del siglo XX. Homenaje al Prof. Garrido Falla”, Tomo 2, Ed. Complutense, Madrid, 1992, pp. 971-1024].

14 Parada Vázquez, J. R., “Derecho Administrativo. Bienes públicos. Derecho Urbanístico”, 9. a ed., Ed. Marcial Pons, Madrid, 2002, p. 37; siendo una obra imprescindible para el estudio del régimen jurídico de los bienes públicos anterior a la LPAP de 2003.

En relación con esta época, ver Serna Vallejo, M., obra citada, pp. 45-51; García-Manzano Jiménez de Andrade, P., obra citada, pp. 90-91; Parejo Alfonso, L., obra citada, pp. 2391-2393, y Muñoz Machado, S., obra citada, pp. 339-342. 
Corona), si bien los caminos públicos, las calles y plazas de las ciudades, los ríos navegables, playas y riberas del mar, los puertos, las radas, etc. y en general las porciones del territorio nacional no susceptibles de propiedad privada se consideran como bienes ("dependencias" dice) de dominio público. Seguidamente, el Código Civil de 1804 (arts. 538 a 541) reitera lo establecido en la Ley citada en relación con el dominio público.

Sobre la base de estas normas, la doctrina (principalmente Proudhon en su obra "Tratado de dominio público o de la distinción de bienes considerados principalmente por su rendimiento al dominio público", publicado en 1833-1834) distingue los bienes de dominio público nacional (integrando el dominio público municipal), como los ríos, los caminos públicos y las carreteras, destinados al uso de todos, por lo que son inalienables e imprescriptibles y sobre los que el Estado no ostenta la propiedad, al pertenecer a todos, sino únicamente los poderes de vigilancia y protección para garantizar su disfrute por los ciudadanos. Junto a estos se distinguen los bienes productivos, o el dominio privado del Estado, sobre los que el mismo se considera propietario con todos los poderes de disposición correspondientes ya que se consideran enajenables y prescriptibles, y cuyos rendimientos se integran en la Hacienda pública. Además, se prevén asimismo los bienes comunales de los Municipios, que pertenecen exclusivamente a éstos, tales como bosques y pastos, y que únicamente pueden ser utilizados por los vecinos. De esta forma, se clarifican los conceptos (dominio público y dominio privado), las facultades de la Administración y las prerrogativas que ostenta sobre los mismos, e incluso la adscripción de los conflictos a la jurisdicción administrativa, y por ello se aceptará en la jurisprudencia y en la legislación posterior; si bien a principios del siglo XX se producirá un interesante debate doctrinal sobre la materia (principalmente entre Hauriou y Duguit) ${ }^{15}$.

Esta distinción de los bienes de dominio público y de dominio privado, y su incipiente régimen, se trasladará a España fruto de los textos doctrinales (principalmente de Colmeiro, que distingue los bienes públicos, los bienes del Estado y los bienes de las Corporaciones locales) ${ }^{16}$, con gran influencia francesa, y posteriormente ya en los textos legales, desde mediados del siglo XIX ${ }^{17}$, en la Ley de Propiedad Literaria de 1847 , en las normas reglamentarias reguladoras de 1845 y 1851 sobre baldíos, en la Legislación sobre carreteras ${ }^{18}$ y ferrocarriles de $1848,1855,1857$ y 1877 , que se refie-

15 Serna Vallejo, M., obra citada, pp. 50-51; García-Manzano Jiménez de Andrade, P., obra citada, pp. 92-95, y Parejo Alfonso, L., obra citada, pp. 2393-2396.

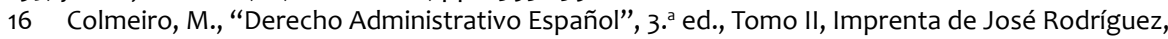
Madrid, 1865, p. 111 y ss. [La edición electrónica puede verse en http://books.google.es/books?id=MGIGRB $\mathrm{H} 4 \mathrm{mOEC}$ \&printsec $=$ frontcover\&dq=Colmeiro $\# \mathrm{v}=$ onepage \&q=\&f=false $]$.

17 Sobre la legislación mencionada, ver Menéndez Rexach, Á., "El Dominio Público como institución jurídica: configuración histórica y significado actual en el Derecho Público Español”, Revista Jurídica de la Universidad Autónoma de Madrid, n. 10/2004, pp. 209-217. También, Serna Vallejo, M., obra citada, pp. 52-54, y Muñoz Machado, S., obra citada, pp. 342-346.

18 Sobre la Legislación histórica de carreteras ver Fernández de Gatta Sánchez, D., “Riesgo, seguridad, circulación de vehículos, carreteras y obligaciones de la Administración Pública”, Revista Tráfico y 456 Sufridos en Accidentes de Tráfico", en Quintana López, T. (Dir.), y otros, "La Responsabilidad Patrimonial 
ren al concepto de servicio público, en la Legislación hipotecaria de 1861, 1863 y 1864 , y principalmente en las importantes Leyes de Aguas de 1866 (cuya Comisión redactora del Proyecto estimó necesario explicar los conceptos de "dominio público de la Nación” y de “dominio particular del Estado”, y así se plasmó en su Exposición de Motivos), de Minas de 1868 y General de Obras Públicas de 1877, que clarifican los conceptos, amplían el contenido del dominio público y distinguen los bienes destinados al uso general de los vinculados a un servicio público (cuyo concepto, para contraponerlo a los servicios particulares, es equivalente a dominio y uso público).

Estas clasificaciones de los bienes públicos, con la definitiva diferenciación entre dominio público y dominio privado del Estado, y su consiguiente régimen jurídico, ya nítidamente vinculados a la trascendencia de los bienes públicos para la sociedad y el propio Poder Público, se reflejan nítidamente en el Código Civil de $1889^{19}$, cuyo art. 339 se refiere a los bienes de dominio público (destinados al uso público, como caminos, canales, ríos, torrentes, puertos y puentes construidos por el Estado, las riberas, playas, radas y análogos) y a los que pertenecen privativamente al Estado sin ser de uso común y están destinados a algún servicio público o al fomento de la riqueza nacional (como murallas, fortalezas y demás obras de defensa del territorio, y las minas mientras no se otorgue su concesión). Además el texto precisa que los restantes bienes del Estado en que no concurran las circunstancias anteriores tienen el carácter de propiedad privada (art. 340), que los bienes de dominio público pasan a formar parte de los bienes de propiedad del Estado cuando dejen de estar destinados al uso general o a la defensa del territorio (art. 341), y se refiere también al Patrimonio Real (art. 342) y a los bienes de las Provincias y de los pueblos, de uso público o patrimoniales (arts. 343 y 344).

Posteriormente, se reproducirá en España también el debate francés sobre la naturaleza del dominio público, asumiéndose por la mayoría de la doctrina y la jurisprudencia (y posteriormente la propia Legislación en la materia) que el mismo es una verdadera propiedad, pero especial, lo que conlleva determinadas facultades para la Administración titular del mismo.

Por otra parte, en cuanto a los bienes patrimoniales ${ }^{20}$, debe tenerse en cuenta que desde la Edad Media y el Antiguo Régimen, el Estado de entonces tenía como una importante fuente de ingresos a las propiedades inmobiliarias. Situación que se verá alterada con la Legislación desamortizadora del siglo XIX (Ley Madoz de 1855), pues pretendía aflorar las propiedades "en manos muertas" y ponerlas en venta. Seguidamente se configura la Hacienda, de carácter fiscal, como sustitutoria de los ingresos anteriores (Ley Mon-Santillán de 1845), y se aumentarán los bienes patrimoniales en manos públicas tanto desde la participación del Estado en empresas como

de la Administración Pública. Estudio general y ámbitos sectoriales”, Tomo 2, Ed. Tirant Lo Blanch, Valencia, 2009, pp. 1369-1434.

19 Serna Vallejo, M., obra citada, pp. 54-58.

20 Santamaría Pastor, J. A., "Principios de Derecho Administrativo General”, Tomo II, Ed. lustel, Madrid, 2004, pp. 532-535, y García-Manzano Jiménez de Andrade, P., obra citada, pp. 99-100. 
desde la adquisición de bienes inmobiliarios a través de la Legislación sectorial (en materia forestal, agrícola o urbanística); plasmándose normativamente en la Ley de la Hacienda Pública de 1911, en la Legislación local de los años cincuenta y, como veremos, en la Ley de Patrimonio de 1964.

Además, durante el siglo XIX se va a afianzar el régimen de protección material, y sus técnicas, de los bienes públicos, incidiendo de manera importante en la propia formación del propio Derecho Administrativo ${ }^{21}$, debido a que el inicio del desarrollo industrial exige una serie de infraestructuras y bienes públicos (que evolucionan con el tiempo) adecuados para las necesidades de la sociedad y de ese proceso (p. ej., las vías de comunicación), junto a la existencia de otros bienes imprescindibles para los ciudadanos (como el agua), todos los cuales han de ser objeto de protección administrativa para permitir su uso continuado, y evitar en lo posible la producción de daños a otros bienes públicos, derivados de ese uso señalado. Protección administrativa que ya es visible en la Proposición de Ley presentada por Silvela el 12 de noviembre de 1838 sobre la organización de los Consejos de Provincia (Congreso de los Diputados, Diario de Sesiones, $n .^{\circ} 7$, de 16 de noviembre, Ap. $\left.3 .^{\circ}\right)$, en la que respecto a la protección de los bienes públicos, en relación con daños y destrucciones provocados por particulares, reconoce la potestad sancionadora a los Consejos (sin perjuicio de la potestad de los órganos administrativos correspondientes), y su conocimiento se integra en la Jurisdicción administrativa, excluyendo a la civil y a la penal (en determinadas circunstancias, esta última); destacando la Memoria del texto el ejercicio, necesario, de la imposición de multas y otras sanciones para proteger los bienes y que "los tribunales administrativos no castigan por escarmentar.../...Su principal objeto, el que verdaderamente se propone obtener, es la reparación del daño: remediar el mal producido sacando lo necesario del bolsillo del causante".

En esta misma época, como ya señalamos más atrás, algunas normas reguladoras de bienes públicos concretos (teniendo en cuenta otras normas generales de la época) prevén instrumentos y potestades (no siempre administrativas) para su protección, incluyendo las sanciones pecuniarias y el resarcimiento de los daños producidos, en materia forestal y de montes públicos (Ordenanzas Generales de Montes de 1833), canales (Real Orden de 1836 sobre el Canal de Castilla), carreteras y ferrocarriles (ordenanzas de 1842 y reglamento de 1851) y aguas (normas sobre riego de 1838).

Posteriormente, ya con la Legislación sobre los Consejos Provinciales de 1845 en vigor, la evolución normativa mantendrá, y reforzará, las competencias de protección de los bienes públicos en los órganos administrativos correspondientes, tal como es visible, en general, en las Leyes de Ayuntamientos y de Gobierno de las Provincias también de 1845 , en las normas resolutorias de conflictos de competencias de 1846 y 1852 (respecto a los Jefes Provinciales y a los Alcaldes). Consolidación de los poderes de la Administración en materia de protección material de los bienes públi-

21 La idea es destacada, analizando con detalle la protección de los bienes, por Font y Llovet, T., obra citada, pp. 24 y ss.; a quien seguimos. 
cos, incluyendo la potestad sancionadora y la reparación de los daños, que se plasma en la Legislación sobre bienes concretos de la segunda mitad del siglo XIX, como en materia de montes (Ley de 1863 y reglamentos de 1865 y 1884), obras públicas (Ley de 1877 , que hace responsable al concesionario de la obra pública de los daños causados "a la parte de dominio público no ocupada") y aguas (Ley de 1866).

La última fase, ya en el siglo XX, en la evolución de la Legislación en materia de bienes públicos, y de su necesaria protección, está constituida por la Legislación local de los años cincuenta, que regulará los de dominio público y los patrimoniales, y principalmente por la Ley de Patrimonio del Estado de $1964^{22}$, que han constituido el régimen jurídico básico hasta la nueva Ley de 2003.

La Ley de Patrimonio del Estado (Texto Articulado aprobado por Decreto 1022/1964, de 15 de abril, BOE del 23) amplía el concepto de bienes de dominio público, definiéndolos de forma negativa al referirse a los bienes que constituyen el Patrimonio del Estado, al incluir como tales a los bienes que se hallen afectados al uso general o a los servicios públicos (y no sólo a alguno como señalaba el Código Civil), a aquellos bienes que la Ley les confiera expresamente el carácter de demaniales y a los edificios propiedad del Estado en los que se alojen sus órganos; desapareciendo la referencia del Código Civil al criterio del fomento de la riqueza nacional. Por otra parte, se consideran parte del Patrimonio del Estado los bienes que, siendo de su propiedad, no sean demaniales por alguno de los criterios de afectación señalados, los derechos reales y de arrendamiento de los que sea titular el Estado, aquellos de cualquier naturaleza que deriven del dominio de los bienes patrimoniales y los derechos de propiedad incorporal que le pertenezcan (art. 1). Rigiéndose todos ello por la Ley de Patrimonio del Estado y, subsidiariamente, por las normas civiles y mercantiles (art. 2).

De ambos preceptos deriva la concepción del dominio público como una relación de propiedad (SsTS de 17 de marzo de 1980, AR. 2201, de 3 de diciembre de 1982, AR. 7774 , y de 15 de octubre de 1984, AR. 4996), que la propiedad de los bienes demaniales constituye un régimen jurídico especial, que se inspira de varias reglas de protección, como veremos, y que el criterio determinante de la condición demanial no es la naturaleza propia de los bienes sino el relativo a su afectación o destino de los mismos (SsTS de 27 de noviembre de 1985, AR. 6505, y de 1 de octubre de 1986, AR. 6405).

Además, la LPE reconoce, con carácter general, un régimen jurídico especial y exorbitante, respecto a la propiedad privada, al incluir ciertas prerrogativas de la Ad-

22 La Legislación de esta época puede verse en García de Enterría, E., y Escalante, J. A., “Legislación Administrativa Básica”, Ed. BOE, Madrid, 1975.

En relación con la Ley de Patrimonio del Estado, y el régimen jurídico de los bienes públicos que establece, ver, por todos, Parada Vázquez, J. R., obra citada, pp. 9-98; Sanchez Morón, M. (Dir.), y otros, “Los Bienes Públicos (Régimen jurídico)”, Ed. Tecnos, Madrid, 1997, y Santamaría Pastor, J., y Parejo Alfonso, L. (Dir.), y otros, “Derecho Administrativo. La Jurisprudencia del Tribunal Supremo”, Ed. Centro de Estudios Ramón Areces, Madrid, 1989, pp. 477-506, redactadas por Fernández Espinar, L. C.; citándose las referencias jurisprudenciales recogidas en esta obra. 
ministración para proteger sus bienes, patrimoniales o demaniales, tales como el Inventario General de Bienes y Derechos del Estado, la recuperación de la posesión indebidamente perdida, la investigación de la situación de los bienes, la facultad de deslinde, la imposibilidad de los Tribunales de dictar providencias de embargo ni despachar mandamiento de ejecución contra esos bienes (inembargalidad), la inscripción en el Registro de la Propiedad (arts. 6 a 18 y 42-LPE) y el desahucio administrativo (regulado en la Legislación local). Además, en relación con los bienes de dominio público se prevé su imprescriptibilidad (art. 1936 del Código Civil), si bien su inalienabilidad no se encuentra directamente reconocida (arts. 61 y 62-LPE, modificados posteriormente, que regulan el procedimiento para autorizar al Gobierno la venta de "bienes inmuebles del Patrimonio del Estado").

No obstante, ni la LPE ni la Legislación local de esta época reconocen ni regulan una potestad sancionadora general de la Administración para proteger sus bienes patrimoniales o demaniales; quizás por la tradición que en el Derecho Español tiene la regulación de esta potestad en la Legislación sectorial23; aunque la regulación de esta época no era aún muy precisa (p. ej., la Ley de Aguas de 1879 únicamente se refiere a la policía de aguas; la Ley de Costas de 1969 reconoce la policía de moralidad, higiene y salubridad, así como sobre los lugares de baño; la Ley de Puertos de 1928 no incluye referencia alguna; aunque la Ley de Montes de 1957 sí regula las infracciones y sanciones en la materia).

\section{El régimen jurídico actual de los bienes públicos y sus clases: bienes de dominio público o demaniales y bienes patrimoniales}

La Constitución Española de 1978 es la primera en la historia que contiene un precepto sobre el dominio público y otros bienes públicos (art. 132) ${ }^{24}$. En efecto, el mismo reserva a la ley el régimen de los bienes de dominio público y de los comunales; pero no de cualquier forma sino que dicho régimen ha de inspirarse en los principios de inalienabilidad, imprescriptibilidad e inembargalidad, así como su desafectación. En segundo lugar, declara bienes de dominio público estatal los que determine la ley y, en todo caso, la zona marítimo-terrestre, las playas, el mar territorial y los recursos naturales de la zona económica y la plataforma continental. Finalmente, se reserva a la ley, asimismo, la regulación del Patrimonio del Estado y el Patrimonio Nacional, su administración, defensa y conservación.

23 Parada Vázquez, J. R., obra citada, pp. 97-98.

24 Sobre la incidencia de la Constitución Española, ver Font y Llovet, T., “La ordenación constitucional del dominio público", en Varios Autores, “Estudios sobre la Constitución Española. Homenaje al Prof. Eduardo García de Enterría”, Tomo V, Ed. Civitas, Madrid, 1991, pp. 3917-3942; Menéndez Rexach, Á., obra citada, pp.221-223; García-Manzano Jiménez de Andrade, P., obra citada, pp. 101-103; Sánchez Morón, M., “Derecho Administrativo. Parte General”, Ed. Tecnos, Madrid, 2008, pp. 741-744; González García, J. V., “Notas sobre el régimen general del dominio público”, en González García, J. V. (Dir.), y otros, “Derecho de los Bienes Públicos”, 2. a ed. Ed. Tirant Lo Blanch, Valencia 2009, pp. 78-82, y Sainz Moreno, F., “El domi460 nio público: Una reflexión sobre su concepto y naturaleza, cincuenta años después de la fundación de la “Revista de Administración Pública”, Revista de Administración Pública, n. 150/1999, pp. 477-514. 
Del contenido del artículo, a los efectos de este trabajo, debemos resaltar el énfasis constitucional en la protección de los bienes de dominio público, al incluir como esencia de su régimen jurídico los principios de inalienabilidad, imprescriptibilidad e inembargalidad ${ }^{25}$, y del Patrimonio del Estado y del Patrimonio Nacional, pues se reserva a la ley su defensa y conservación. De esta forma, la trascendencia que los bienes públicos han tenido en la historia se ha plasmado, nada menos, que en su regulación constitucional, al resaltarse su protección.

El régimen especial de los bienes de dominio público, derivado de su trascendencia, y, en concreto, este rasgo característico sobre su protección, reafirmado en el precepto, se remarca en la STC 227/1988, de 27 de noviembre, relativa a la Ley de Aguas de 1985, al señalar que

"la incorporación de un bien al dominio público supone no tanto una forma especi-
fica de apropiación por parte de los poderes públicos, sino una técnica dirigida pri-
mordialmente a excluir el bien afectado del tráfico jurídico privado, protegiéndolo
de esta exclusión mediante una serie de reglas exorbitantes de las que son comu-
nes en dicho tráfico iure privato. El bien de dominio público es así ante todo res ex-
tra commercium, y su afectación, que tiene esa eficacia esencial, puede perseguir
distintos fines: Típicamente, asegurar el uso público y su distribución pública me-
diante concesión de los aprovechamientos privativos, permitir la prestación de un
servicio público, fomentar la riqueza nacional (art. 339 del Código Civil), garantizar
la gestión y utilización controlada o equilibrada de un recurso esencial, u otros simi-
lares. Dentro de esta amplia categoría de los bienes demaniales es preciso distin-
guir entre los singularmente afectados a un servicio público o a la producción de
bienes o servicios determinados en régimen de titularidad pública y aquellos otros
que, en cuanto géneros, se declaran no susceptibles de apropiación privada en
atención a sus características naturales unitarias".

Asimismo, el Tribunal Constitucional ha afirmado que el precepto "no es ciertamente una norma atributiva de competencia, sino una reserva de ley" (STC 58/1982, de 27 de julio, FJ n. ${ }^{\circ}$ ); lo que establece "es una reserva de ley -obviamente de ley del Estado- para determinar qué otros bienes han de formar parte de ese dominio público adscrito a la titularidad estatal", y ello porque "la Constitución ha dispuesto así que algunos de los tipos de bienes que doctrinalmente se han definido como perte-

25 González García, J. V., “Notas sobre el régimen general del dominio público”, obra citada, pp. 80-82, destaca la importancia de la inclusión de estos tres principios, al señalar que "la Constitución ha querido introducir el dominio público en un régimen de total indisponibilidad, en la medida que se quiere proteger de todo acto consciente o inconsciente, directo o indirecto que pueda suponer la adquisición del bien por parte de un particular", para añadir de forma gráfica que "se introduce,..., el bien configurado como demonial en una especie de cámara acorazada para protegerlo del régimen general de adquisición de bienes del Código civil” (la cita en p. 80). Por su parte, Font y Llovet, T., "La ordenación constitucional del dominio público", obra citada, p. 3924, señala que el régimen jurídico especial que caracteriza a los bienes demaniales no agota su contenido en el principio de extracomerciabilidad [que se plasma en los tres citados], al no limitarse a la preservación formal de su titularidad en manos públicas, sino que se aplica también a la ordenación del uso de los bienes, para que sea concorde con esa titularidad y con el destino de los bienes; mencionando expresamente la STC 227/1988, de 29 de noviembre (FJ n. ${ }^{\circ} 11$ ), al asumir la idea. 
necientes al demanio ‘natural' formen parte del dominio público del Estado”, aunque "no ha pretendido agotar la lista o enumeración de los géneros de bienes que, asimismo en virtud de sus caracteres naturales, pueden integrarse en el demanio estatal ('en todo caso', reza el art. 132), pero sí ha querido explícitamente reservar a la ley, y precisamente a la ley estatal, la potestad de completar esa enumeración”, refiriéndose "a tipos o categorías genéricas de bienes definidos según sus características naturales homogéneas", pues "cuando se trata de categorías completas de bienes formados por la naturaleza, a semejanza de los que en el propio precepto constitucional se declaran de dominio público, el art. 132.2 exige la demanialización por ley y sólo por ley del Estado" (STC 227/1988, de 29 de noviembre, FJ n. 14). Es más, esta exclusión genérica de bienes del comercio privado (el género de bienes definidos por sus características naturales, por lo que se definen como de dominio público) es competencia del Estado porque afecta a la igualdad esencial de todos los españoles de acuerdo con el art. $149-1 .^{\circ}, 1 .^{\text {a }}$ de la propia Constitución; añadiendo que "a la luz de los antecedentes históricos, no cabe duda de que la regulación de la clasificación primaria de los bienes en susceptibles o no de dominio privado constituye parte de la legislación civil, sin perjuicio del carácter público de la legislación que fije el régimen exorbitante de protección y uso de los bienes públicos" (STC 227/1988, de 29 de noviembre, FJ n.14).

Posteriormente, la STC 149/1991, de 4 de julio, sobre la Ley de Costas, insiste en la necesidad de protección de los bienes demaniales, al señalar que su titularidad estatal implica necesariamente establecer un régimen de protección de los mismos ya que "el mandato del constituyente quedaría burlado si el legislador obrase de modo tal que, aún reteniendo físicamente en el dominio público del Estado la zona marítimo-terrestre, tolerase que su naturaleza o sus características fuesen destruidas o alteradas", por lo que "el legislador estatal no sólo está facultado, sino obligado, a proteger el demanio marítimo-terrestre a fin de asegurar tanto el mantenimiento de su integridad física o jurídica, como su uso público y sus valores paisajísticos" (FJ n. ${ }^{1-C}$ y D).

De acuerdo con la importante incidencia del art. 132-CE (y teniendo en cuenta, asimismo, las competencias del Estado sobre condiciones de igualdad de los españoles, legislación civil, hacienda general, régimen jurídico de las Administraciones, procedimiento administrativo común y contratos y concesiones, ex art. 149-1. ${ }^{\circ}, 1 .^{\mathrm{a}}, 8 .^{\mathrm{a}}$, $14 .^{a}$ y $18 .{ }^{a}-C E$, entre las más destacables), con la nueva estructura territorial de España, con la necesidad de tener en cuenta las nuevas Leyes administrativas (de régimen jurídico y procedimiento común y sobre organización y funcionamiento de la Administración), así como la propia evolución de la sociedad, se hacía absolutamente necesario sustituir la vieja Ley de Patrimonio del Estado de 1964.

Por estas razones (y algunas otras mencionadas en la Exposición de Motivos del nuevo texto $)^{26}$ se aprobó la Ley $33 / 2003$, de 3 de noviembre, de Patrimonio de las

26 Un mayor detalle sobre la necesidad y justificación de la nueva Ley puede verse en Uría Fernández, F., "La Ley de Patrimonio de las Administraciones Públicas como instrumento al servicio de una nueva política patrimonial del Estado”, en Chinchilla Marín, C. (Coord.), y otros, “Comentarios a la Ley 33/2003, 
Administraciones Públicas (BOE del 4), basada en las competencias nacionales señaladas y en la que una gran parte de sus preceptos tienen el carácter de legislación de aplicación plena o básica a efectos constitucionales (arts. 1 y 2, y DF-2. ${ }^{\mathrm{a}}$ ), si bien debe tenerse en cuenta la aplicación preferente, como normas especiales, de las Leyes reguladoras de los bienes demaniales concretos y demás propiedades administrativas (tal como se prevé en el art. 5-4. $\left.{ }^{\circ}\right)^{27}$.

La nueva Ley de Patrimonio de las Administraciones Pública ${ }^{28}$ tiene por objeto establecer las bases del régimen patrimonial de las Administraciones Públicas y regular, de conformidad con el art. 132 de la Constitución, la administración, defensa y conservación del Patrimonio del Estado; desatacando asimismo la finalidad esencialmente conservadora y defensora de estos bienes (art. 1-LPAP). Pretende, como señala la Exposición de Motivos (Apdo. I, último párrafo), "sentar las bases normativas para la formulación y desarrollo de una política global relativa a la gestión de los bienes públicos estatales, abordar los diferentes problemas que plantean las relaciones entre las distintas Administraciones públicas en materia patrimonial, efectuar una detenida revisión de las normas que rigen la administración de bienes y actualizar la regulación del patrimonio público empresarial”.

En cuanto al ámbito de aplicación, con una finalidad homogeneizadora y de realizar un completo diseño, la LPAP establece el régimen jurídico patrimonial de la Administración General del Estado y de los organismos públicos vinculados a ella o dependientes de la misma, y se aplica a las Comunidades Autónomas, a la Administración Local y a las entidades de Derecho Público vinculadas o dependientes de ellas, de acuerdo con lo dispuesto en la DF 2. ${ }^{\text {a }}$ (art. 2-LPAP) ${ }^{29}$. Sin embargo, y aunque parece que este ámbito es completo, en relación con la Administración General del Estado y sus organismos, la Ley incluye un buen número de exclusiones que hacen más complejo el marco norma-

del Patrimonio de las Administraciones Públicas”, Ed. Thomson-Civitas, Cizur Menor (Navarra), 2004, pp. 25-41, y Sanz Gandasegui, F. A., y Uría Fernández, F., “Objeto y ámbito de aplicación. Artículos 1 y 2”, en DE Fuentes Bardajía, J. (Dir.), y otros-Abogacía General del Estado (Dirección General del Servicio Jurídico del Estado), “Comentarios a la Ley de Patrimonio de las Administraciones Públicas”, Ed. Abogacía General del Estado y Ed. Thomson-Aranzadi, Cizur Menor (Navarra), 2008, pp. 118-123.

27 Así, en relación con aguas y minas vid. el trabajo de González Iglesias, M. A., en este mismo Número.

28 En general sobre la Ley, ver Chinchilla Marín, C. (Coord.), y otros, “Comentarios a la Ley 33/2003, del Patrimonio de las Administraciones Públicas”, Ed. Thomson-Civitas, Cizur Menor (Navarra), 2004; DE Fuentes Bardajía, J. (Dir.), y otros-Abogacía General del Estado (Dirección General del Servicio Jurídico del Estado), “Comentarios a la Ley de Patrimonio de las Administraciones Públicas”, Ed. Abogacía General del Estado y Ed. Thomson-Aranzadi, Cizur Menor (Navarra), 2008; González García, J. V. (Dir.), y otros, “Dere-

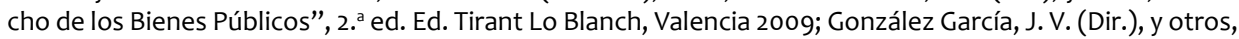
“Diccionario de Obras Públicas y Bienes Públicos”, Ed. lustel, Madrid, 2007, y Mestre Delgado, J. F. (Dir.), y otros, "El Régimen Jurídico del Patrimonio de las Administraciones Públicas (Comentario a la Ley 33/2003, de 3 de noviembre)", Ed. El Consultor, Madrid, 2004.

29 Sobre los arts. 1 y 2 de la Ley, ver Mestre Delgado, J. F., "Objeto y ámbito de aplicación de la Ley. Artículos 1 y 2”, en Mestre Delgado, J. F. (Dir.), y otros, obra citada, pp. 1-15; Sanz Gandasegui, F. A., y Uría Fernández, F., "Objeto y ámbito de aplicación. Artículos 1 y 2”, en De Fuentes Bardajía, J. (Dir.), y otros-Abogacía General del Estado, obra citada, pp. 109-144, y Santamaría Pastor, J. A., “Objeto y ámbito. La tipología de los bienes públicos y el sistema de competencias”, en Chinchilla Marín, C. (Coord.), y otros, obra citada, pp. 43-75. 
tivo (Disp. Ad. $1 .^{\mathrm{a}}$ a $8 .^{\mathrm{a}}$ y $19 .{ }^{\mathrm{a}}$ a $21 .^{\mathrm{a}}$ ), existen patrimonios que no se encuentran integrados en el ámbito de la Ley (de fundaciones o consorcios, p. ej.), e incluso posteriormente se establecen regímenes jurídicos, en otras leyes, que contradicen la propia LPAP ${ }^{30}$.

Por lo que se refiere a la aplicación de la Ley a las Comunidades Autónomas y a las Administraciones Locales, es revelador el Dictamen del Consejo de Estado de 3 de abril de 2003 (Ref. 805/2003), relativo al Anteproyecto de LPAP, al señalar que

“...para delimitar las competencias normativas que corresponden al Estado y a las Comunidades Autónomas en relación con los patrimonios públicos hay que acudir, primeramente, al artículo 149 de la Constitución, pues, si bien este precepto no contempla expresamente el patrimonio de las Administraciones Públicas como un ámbito material sustantivo, sí contiene otros títulos competenciales que, por su relación con la materia patrimonial, permiten afirmar la competencia del Estado para dictar las normas básicas por las que se ha de regir el patrimonio de todas las Administraciones Públicas (artículo 149.1.18.a), o incluso su competencia exclusiva en determinadas materias íntimamente relacionadas con la regulación de los patrimonios públicos (artículo 149.1.8.a).

Efectivamente, la regla 18. ${ }^{\text {a }}$ del artículo 149.1 de la Constitución atribuye al Estado la competencia exclusiva para dictar "las bases del régimen jurídico de las Administraciones Públicas”, título atributivo en el que se puede incluir la regulación básica del patrimonio de las Administraciones Públicas. Junto a él, y siguiendo la jurisprudencia constitucional, deben tenerse en cuenta otros títulos de alcance más limitado y aplicación más específica, como el relativo a la "legislación básica en materia de contratos y concesiones administrativas" (también incluido en la regla 18. a del artículo 149.1), o el que atribuye al Estado competencia exclusiva en materia de "legislación civil; sin perjuicio de la conservación, modificación y desarrollo por las Comunidades Autónomas de los derechos civiles, forales o especiales, allí donde existan" (artículo 149.1.8. ${ }^{a}$ ).

A la vista de lo anterior, puede afirmarse que corresponde al Estado establecer el régimen jurídico del Patrimonio del Estado y dictar las bases del régimen jurídico del Patrimonio de las Administraciones Públicas. Por otra parte, corresponde a las Comunidades Autónomas dictar el régimen jurídico de sus respectivos patrimonios en el marco de la legislación básica del Estado... /..., y con respeto en todo caso a la legislación civil, que es competencia exclusiva del Estado".

Por lo que se refiere a las Administraciones Locales, la LPAP, de acuerdo con su DF-2. ${ }^{a}$, se aplica a las mismas, si bien asimismo debe tenerse en cuenta la Legislación básica sobre régimen local, y la normativa autonómica de desarrollo ${ }^{31}$.

30 Es sintomático el ejemplo que aporta Santamaría Pastor, J. A., “Objeto y ámbito. La tipología de los bienes públicos y el sistema de competencias”, en Chinchilla Marín, C. (Coord.), y otros, obra citada, p. 54, relativo a la Ley 48/2003, de 26 de noviembre, sobre Régimen Económico y de Prestación de Servicios de los Puertos de Interés General (BOE del 27), que sólo unos días después de la publicación de la LPAP establece otro régimen jurídico diferente, modificando tácitamente la Disp. Ad. 5 . $^{\text {a-LPAP. }}$

31 Castillo Blanco, F. A., "El Patrimonio de las Entidades Locales tras la aprobación de la Ley de Pa464 trimonio de las Administraciones Públicas", en Mestre Delgado, J. F. (Dir.), y otros, obra citada, pp. 19 y ss. 
A efectos legales, y siendo una novedad destacable, el art. 3-LPAP define el patrimonio de las Administraciones, señalando, de forma amplia y general, que "está constituido por el conjunto de sus bienes y derechos, cualquiera que sea su naturaleza y el título de su adquisición o aquel en virtud del cual les hayan sido atribuidos", incluyendo pues tanto a los bienes demaniales como a los patrimoniales, pero excluyendo, no obstante, "el dinero, los valores, los créditos y los demás recursos financieros de su hacienda ni, en el caso de las entidades públicas empresariales y entidades análogas dependientes de las comunidades autónomas o corporaciones locales, los recursos que constituyen su tesorería" 32 .

Seguidamente, la LPAP establece que, por razón del régimen jurídico al que están sujetos, los bienes del Patrimonio de las Administraciones pueden ser de dominio público o demaniales y de dominio privado o patrimoniales (art. 4); reiterando así una distinción histórica bien conocida, siendo más novedosa la inclusión de ambos tipos de bienes en el concepto de "patrimonio de las Administraciones" y, como veremos inmediatamente, la aplicación a ambos de un régimen común (especialmente en cuanto a su protección), relativizándose esta distinción, tal como señala la STC 166/1998, de 15 de julio (FJ n. ${ }^{\circ} 11$ ) 33 . Por otra parte, debe tenerse en cuenta que esta clasificación no es completa, como reflejan los bienes del Patrimonio Nacional (que tienen las características materiales de los demaniales pero cuya titularidad es del

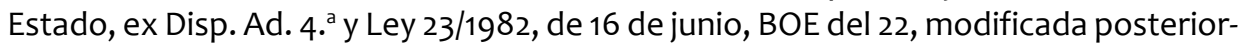
mente) y la no mención a los bienes comunales (que, como sabemos, tienen reflejo constitucional) ${ }^{34}$.

De acuerdo con la clasificación anterior, a continuación la LPAP establece los bienes que se integran en cada una de las dos categorías.

Así, el art. 5 considera bienes de dominio público o demaniales a aquellos que, siendo de titularidad pública, se encuentren afectados al uso general o al servicio público, así como aquellos a los que una ley otorgue expresamente tal carácter. Asimismo, son bienes demaniales, en todo caso, los mencionados en el art. 132-CE (es decir, la zona marítimo-terrestre, las playas, el mar territorial y los recursos naturales

32 Sobre este precepto, criticando las exclusiones por ser poco comprensibles al prescindir del mayor volumen económico de que son titulares las Administraciones, vid. Santamaría Pastor, J. A., “Objeto y ámbito. La tipología de los bienes públicos y el sistema de competencias", obra citada, p. 64., y "Principios de Derecho Administrativo General”, obra citada, pp.522-523, y Menéndez García, P., “Ámbito objetivo de regulación y extensión del dominio público”, obra citada, pp. 125-132, quien estima que la exclusión se justifica en la necesidad de preservar estos recursos financieros de la posibilidad de un embargo. Por su parte, Uría Fernández, F., “Patrimonio de las Administraciones Públicas. Artículos 3 a 9”, obra citada, pp. 148-149, ve la exclusión razonable, al no tener mucho sentido aplicar a estos bienes los rígidos procedimientos de la propia Ley, al ser inaplicable una regulación pensada para bienes muebles e inmuebles y porque la distinción entre el Tesoro y el Patrimonio es tradicional en la Hacienda Pública española.

33 Uría Fernández, F., "Patrimonio de las Administraciones Públicas. Artículos 3 a 9”, obra citada, pp. $154-155$.

34 Santamaría Pastor, J. A., “Objeto y ámbito. La tipología de los bienes públicos y el sistema de competencias”, obra citada, pp. 76-77. 
de la zona económica y la plataforma continental). Por último, se consideran, también en todo caso, bienes demaniales los inmuebles de titularidad de la Administración General del Estado o de los organismos vinculados a ella o dependientes de la misma en que se alojen servicios, oficinas o dependencias de sus órganos o de los Órganos Constitucionales del Estado ${ }^{35}$.

En relación con el primer grupo, sin duda el más importante, la Ley distingue los bienes de dominio público por el instrumento mediante el que se integran en esta categoría (haciendo referencia a la tradicional distinción entre bienes demaniales por afectación o por naturaleza), entre aquellos que lo son mediante el acto administrativo de su afectación a un uso general o al servicio público, y por el que, alterando su naturaleza jurídica, adquieren tal condición jurídica (como señalan con precisión los arts. 65 y 66-LPAP), y aquellos otros que lo son porque una ley (nacional, ex arts. 33, y 149-1. 1. ${ }^{\mathrm{a}}$ y $8 .^{\mathrm{a}}, \mathrm{CE}$ ) les otorga expresa y directamente esta condición de bienes demaniales, no requiriéndose en este supuesto actividad administrativa alguna (salvo los actos de comprobación correspondientes, en su caso), atendiendo únicamente al cumplimiento de las características físicas establecidas por la ley. En este sentido es clarificadora la doctrina constitucional de la STC 227/1988, de 29 de noviembre al señalar que

"Así se desprende, por lo demás, del inciso inicial de este art. 132.2: 'Son de dominio público estatal los que determine la ley...'. Tanto el verbo utilizado -'son', en vez de la expresión 'pueden ser'-, como la misma reserva absoluta de ley indican a las claras que la Constitución se está refiriendo no a bienes específicos o singularmente identificados, que pueden ser o no de dominio público en virtud de una afectación singular, sino a tipos o categorías genéricas de bienes definidos según sus características naturales homogéneas" (FJ n. ${ }^{\circ 14)}$.

En segundo lugar, la LPAP reitera, como no podía ser de otra forma, la declaración de demanialidad de los bienes mencionados en la Constitución Española; declaración que materialmente obedece a las mismas razones que en el supuesto legal anterior (es decir, los caracteres naturales o físicos homogéneos o unitarios de los mismos), aunque la protección de tal declaración es la que corresponde al Texto Constitucional.

35 En relación con el dominio público, y las clases de bienes demaniales, ver Fernández Acevedo, R., “El Patrimonio de las Administraciones Públicas: concepto y principios generales”, en Mestre Delgado, J. F. (Dir.), y otros, "El Régimen Jurídico del Patrimonio de las Administraciones Públicas (Comentario a la Ley 33/2003, de 3 de noviembre)”, obra citada, pp. 141-176; González García, J. V., "La titularidad de los bienes de dominio público”, Ed. Marcial Pons, Madrid, 1998, y “Dominio Público”, en González García, J. V. (Dir.), y otros, “Diccionario de Obras Públicas y Bienes Públicos”, Ed. lustel, Madrid, 2007, pp. 322-335; Santamaría Pastor, J. A., “Objeto y ámbito. La tipología de los bienes públicos y el sistema de competencias”, obra citada, pp. 75-85, y Uría Fernández, F., “Patrimonio de las Administraciones Públicas. Artículos 3 a 9", obra citada, pp. 162-163.

Sobre la afectación, ver González García, J. V., "Notas sobre el régimen general del dominio público”, en González García, J. V. (Dir.), y otros, “Derecho de los Bienes Públicos”, 2. a ed. Ed. Tirant Lo Blanch, Valencia 2009, pp. 82-86, y Chinchilla Peinado, J. A., "Régimen jurídico de la afectación, desafectación, muta466 ción de destino, adscripción y desadscripción de los bienes y derechos públicos”, Revista Gallega de Administración Pública, n. $37 / 2004$, pp. 15-64, así como las obras generales citadas. 
Finalmente, la propia LPAP, siguiendo la tradición de nuestro Derecho, declara de dominio público los inmuebles, de titularidad de la Administración General del Estado o de organismos público vinculados a ella o dependientes de la misma en que se alojen servicios, oficinas o dependencias de sus propios órganos o de los Órganos Constitucionales del Estado; destacando así la trascendencia de la actividad administrativa o constitucional que se desarrolla en los mismos, aunque no sin algunos aspectos críticos ${ }^{36}$.

En relación a su régimen jurídico ${ }^{37}$, el mismo art. 5-LPAP se remite en primer término a las leyes y disposiciones especiales que les sean de aplicación; a falta de estas normas especiales, se rigen por la LPAP y las disposiciones que la desarrollen o complementen, y finalmente las normas generales de Derecho Administrativo y, en su defecto, las de Derecho Privado tienen el carácter de derecho supletorio. Derecho aplicable que refleja el carácter supletorio de la propia LPAP, al ceder su aplicación ante las leyes especiales reguladoras de los bienes demaniales concretos, cuya regulación no siempre sigue los parámetros de ésa Ley. La explicación a este sistema de fuentes se refleja en la Exposición de Motivos -LPAP, al señalar que
"la regulación de los bienes y derechos de dominio público.../... está pensada para operar con carácter supletorio respecto de la legislación especial. La aplicación en primer grado de sus normas se producirá, por tanto, sólo en relación con aquellos bienes demaniales por afectación que carecen de una disciplina específica, señala- damente, los edificios administrativos, cuyos problemas de gestión son objeto de particular consideración en el texto, y que han servido de guía para la regulación efectuada".

Además, la LPAP incluye en su art. 6 una serie de principios relativos a los bienes y derechos demaniales a los que ha de sujetarse su gestión por todas las Administraciones Públicas, por su carácter básico. Precepto novedoso, que sigue la línea de otras Leyes actuales, y que debe resaltarse porque algunos de los mencionados reflejan la trascendencia de los bienes demaniales y de su protección ${ }^{38}$. En este sentido, la

36 Uría Fernández, F., “Patrimonio de las Administraciones Públicas. Artículos 3 a 9”, obra citada, p. 163 , pone en duda la aplicación de este régimen a tales edificios y dependencias cuando muchos servicios administrativos se prestan en inmuebles en régimen de arrendamiento sin mayores problemas y por el hecho de que en tales edificios demaniales se prestan a actividades no vinculadas a competencias administrativas o a la prestación de servicios públicos (como almacenes), o al menos no a las más importantes.

37 Fernández Acevedo, R., "El Patrimonio de las Administraciones Públicas: concepto y principios generales”, obra citada, pp. 176-178, y Uría Fernández, F., “Patrimonio de las Administraciones Públicas. Artículos 3 a 9", obra citada, pp. 163-165.

38 No obstante, Santamaría Pastor, J. A., “Objeto y ámbito. La tipología de los bienes públicos y el sistema de competencias", obra citada, pp. 88-89, habla, refiriéndose a los arts. 6 y 8-LPAP, de "absurda moda de los <principios>", estima que ambos son "perfectamente prescindibles" al referirse a reglas reiteradas, incluyendo asimismo una ácida crítica a la inclusión de principios similares en algunas leyes recientes y abogando por la supresión de preceptos parecidos, y Uría Fernández, F., "Patrimonio de las Administraciones Públicas. Artículos 3 a 9”, obra citada, p. 170, lo considera innecesario, porque reitera principios y reglas ya establecidos. Por el contrario, en relación con los relativos a los bienes demaniales, González García, J. V., "Bienes Patrimoniales”, obra citada, p. 334, reconoce su alcance diferente y su carácter didác- 
Exposición de Motivos-LPAP explica su inclusión en el texto legal (si bien se refiere también a los principios relativos a los bienes patrimoniales) porque "responden en última instancia a la consideración de estos bienes y derechos como activos que deben ser administrados de forma integrada con los restantes recursos públicos, de acuerdo con los criterios constitucionales de eficiencia y economía, y haciendo efectiva su vocación de ser aplicados al cumplimiento de funciones y fines públicos".

En efecto, y destacando únicamente los relativos a la protección de estos bienes, ese precepto comienza recordando los de inalienabilidad, inembargabilidad e imprescriptibilidad (letra a), de carácter constitucional, para continuar con el relativo al ejercicio diligente de las prerrogativas que la Ley u otras especiales otorguen a las administraciones Públicas, garantizando su conservación e integridad (letra e), y el principio de identificación y control a través de inventarios o registros adecuados (letra f), con la finalidad de garantizar su conservación e integridad.

La segunda gran categoría de bienes del patrimonio de las Administraciones Públicas está constituida por bienes y derechos de dominio privado o patrimoniales ${ }^{39}$, que son bienes y derechos de titularidad de la Administración y naturaleza jurídico-privada, que sirven de soporte para la realización de funciones públicas, sin estar afectos a un uso o servicio público; no gozando pues de las características de los bienes demaniales en relación con su comercio ${ }^{40}$. La LPAP (art. 7-1. ${ }^{\circ}$ y $2 .^{\circ}$ ) recoge, y define en primer lugar, de manera residual, al considerar como tales a aquellos que, siendo de titularidad de las Administraciones Públicas, no tengan el carácter de demaniales, y a continuación asimismo incluir, en todo caso, como bienes patrimoniales de la Administración General del Estado y sus organismos públicos los derechos de arrendamiento, los valores y títulos representativos de acciones y participaciones en el capital de sociedades mercantiles o de obligaciones emitidas por éstas, así como contratos de futuros y opciones cuyo activo subyacente esté constituido por acciones o participaciones en entidades mercantiles, los derechos de propiedad incorporal y los derechos de cualquier naturaleza que se deriven de la titularidad de los bienes y derechos patrimoniales. Además de los señalados, existen otros bienes patrimoniales reconocidos específicamente por la legislación sectorial (como, p. ej., el patrimonio económico-industrial).

tico, y en relación con los bienes patrimoniales afirma, p. 141, que "más allá de las críticas que se han vertido, pueden servir para una función didáctica en la aplicación de los preceptos de gestión patrimonial”.

39 En relación con los bienes patrimoniales, vid. Chinchilla Marín, C., "Bienes patrimoniales. Concepto y formas privilegiadas de adquisición”, Ed. Marcial Pons, Madrid, 2001; Fernández Acevedo, R., “El Patrimonio de las Administraciones Públicas: concepto y principios generales", obra citada, pp. 182-192; Garrido Falla, F., “El dominio privado de la Administración”, en Varios Autores, “Estudios en Homenaje a Jordana de Pozas”, Tomo III, Vol. 1. , “Estudios de Derecho Administrativo General”, Ed. Instituto de Estudios Políticos, Madrid, 1961; González Bustos, M. ${ }^{a}$ Á., “Los Bienes de Propios: Patrimonio Local y Administración”, Ed. M. Pons, Madrid, 1988; González García, J. V., “Bienes Patrimoniales”, en González García, J. V. (Dir.), y otros, “Diccionario de Obras Públicas y Bienes Públicos”, obra citada, pp. 133-141, y "Patrimonio y bienes patrimoniales de las Administraciones Públicas”, en González García, J. V. (Dir.), y otros, "Derecho de los Bienes Públicos”, obra citada, pp. 109-145; Santamaría Pastor, J. A., “Objeto y ámbito. La tipología de los bienes públicos y el sistema de competencias", obra citada, pp. 75-85, y Uría Fernández, F., "Patrimonio de las Administraciones Públicas. Artículos 3 a 9", obra citada, pp. 178 y siguientes.

40 Moreu Carbonell, E., “El Derecho Público de los Bienes”, op. cit., p. 335. 
La principal diferencia con los bienes demaniales es que, como ya sabemos, tienen naturaleza privada, no están afectados al uso general o al servicio público y, por ello, no gozan de las características de inalienabilidad, inembargabilidad e imprescriptibilidad; siendo posible, pues, que sean objeto de operaciones comerciales.

Las finalidades de los bienes patrimoniales están perfectamente señaladas en la STC 166/1998, de 15 de julio, que aunque se refiere a los bienes patrimoniales de las Entidades Locales son perfectamente aplicables a los de las restantes Administraciones, al indicar que

“... los bienes inmuebles patrimoniales o de propios de dichas Entidades están destinados a obtener el máximo rendimiento económico para aquéllas, al igual que ocurre con los bienes cuyo titular es un particular. Su valor en el mercado, en efecto, permite que las Entidades locales puedan recurrir al crédito incluso mediante la constitución de una garantía real.../...; bien proceder a su enajenación y obtener un ingreso extraordinario de Derecho privado, bien conservarlos como fuente de rentas para el erario de la Entidad...", y “... no cabe olvidar otra finalidad inherente tanto al patrimonio de los entes públicos como al de los sujetos privados, en cuanto conjunto de bienes, presentes y futuros: La de responder del cumplimiento de las obligaciones contraídas por su titular (art. 1.911 C.C.)".

En este mismo sentido, el art. 8-2. ${ }^{\circ}$, LPAP, señala que, en todo caso, la gestión de los bienes patrimoniales deberá coadyuvar al desarrollo y ejecución de las distintas políticas públicas en vigor y, en particular, al de la política de vivienda, de forma coordinada con las Administraciones competentes.

En relación con su régimen jurídico, el art. 7-3..$^{\circ}$ LPAP ${ }^{41}$, establece que el régimen de adquisición, administración, defensa y enajenación de los bienes y derechos patrimoniales es el previsto en la propia LPAP y en las disposiciones que la desarrollen y complementen; siendo de aplicación supletoria las normas de Derecho Administrativo, en relación con las cuestiones relativas a la competencia para adoptar los correspondientes actos y al procedimiento correspondiente, y las de Derecho Privado, respecto a los restantes aspectos de su régimen jurídico.

Por su parte, de forma similar al supuesto de los bienes demaniales, el art. 8-LPAP42 incluye los principios relativos a los bienes y derechos patrimoniales, entre los cuales destacamos, por su relación con su conservación y protección, el relativo a la identificación y control a través de inventarios o registros adecuados (letra d).

41 Fernández Acevedo, R., “El Patrimonio de las Administraciones Públicas: concepto y principios generales", obra citada, pp. 190-192

42 En relación con estos principios, González García, J. V., “Bienes Patrimoniales”, obra citada, p. 141, afirma que tienen un valor jurídico directo variado y una importancia desigual, y que "más allá de las críticas que se han vertido, pueden servir para una función didáctica en la aplicación de los preceptos de gestión patrimonial". 


\section{EL SISTEMA DE PROTECCIÓN DE LOS BIENES PÚBLICOS}

\section{Referencias generales}

Teniendo en cuenta la trascendencia de los bienes públicos, debido a su papel esencial para permitir que las Administraciones Públicas, y los Poderes Públicos en general, cumplan las funciones establecidas en el Ordenamiento Jurídico y que los ciudadanos gocen de ciertas prestaciones y servicios públicos, desde sus orígenes, como hemos visto, los mismos han tenido un sistema público de protección con la finalidad de garantizar su conservación y mantener su integridad, precisamente para permitir que las Administraciones Públicas continúen desarrollando las funciones señaladas con los mismos. De hecho, históricamente, la característica más destacable de estos bienes, principalmente de los demaniales, es su sujeción a un enérgico sistema de protección, justificado en las habituales amenazas de apropiaciones indebidas y en su deterioro ${ }^{43}$. Por lo que, no es extraño que la "defensa y conservación" de estos bienes haya tenido reflejo constitucional, en el art. 132-CE, como una de las características esenciales de su naturaleza y de su régimen jurídico, incluida en la reserva de ley prevista en la materia.

Históricamente, este régimen de protección se articula alrededor de los bienes demaniales, al ser considerados de mucha mayor importancia para el Poder Público y para la prestación de sus funciones; razón por la que estos bienes se declaran fuera del comercio. Frente a ellos, los bienes patrimoniales, como no tenían que servir a las importantes funciones públicas de los demaniales, tendrán un sistema de protección cercano a las propiedades privadas normales. Situación diversa que se refleja claramente en el Código Civil, si bien con el paso del tiempo esta diversidad en el régimen de protección comenzará a diluirse al darse más trascendencia a las funciones administrativas que permiten ejercer los bienes públicos, con lo que se articulará un sistema común de protección de todos los bienes públicos, aplicable tanto a los demaniales como a los patrimoniales.

De acuerdo con el art. 132-CE, con el art. 1-LPAP, que integra la defensa y la conservación de estos bienes en el objeto del propio texto legal, así como con los principios de gestión de los bienes demaniales y patrimoniales, en los que se refleja la protección de los mismos (arts. 6 y 8-LPAP), el novedoso, frente a las Leyes anteriores, art. 28-LPAP ${ }^{44}$ establece de forma general, con claridad y amplitud (por su carácter de legislación básica a efectos constitucionales, ex DF-2. ${ }^{a}$, LPAP) que 583.

43 Santamaría Pastor, J. A., "Principios de Derecho Administrativo General”, obra citada, pp. 582-

44 Sobre este precepto, y la protección general de los bienes públicos, ver Abajo Quintana J. J., “De la obligación de proteger y defender el patrimonio. Artículos 28 y 29 ", en De Fuentes Bardajía, J. (Dir.), y otros-Abogacía General del Estado, obra citada, pp. 391-397; Ballesteros Moffa, L. A., "Protección y defensa del patrimonio: obligación administrativa, cooperación y límites de disponibilidad", en Chinchilla Ma-

470 rín, C. (Coord.), y otros, obra citada, pp. 201-246; González García, J. V., “Notas sobre el régimen general del dominio público", en González García, J. V. (Dir.), y otros, "Derecho de los Bienes Públicos”, obra citada, 
“Las Administraciones públicas están obligadas a proteger y defender su patrimonio. A tal fin, protegerán adecuadamente los bienes y derechos que lo integran, procurarán su inscripción registral, y ejercerán las potestades administrativas y acciones judiciales que sean procedentes para ello".

Además, y en el mismo sentido, el art. 29-LPAP45, cuyo carácter básico sólo se reconoce al párrafo segundo, obliga a los titulares de órganos que tengan a su cargo bienes o derechos del Patrimonio del Estado a velar por su custodia y defensa, así como a los titulares de concesiones y otros derechos sobre los bienes de dominio público.

Preceptos con los que se inicia el Título II de la Ley, sobre "Protección y Defensa del Patrimonio" (arts. 28 a 64), y que se completa con la regulación del "Régimen sancionador" (Título IX, arts. 192-197).

Este régimen protector es común para los bienes públicos, lo que constituye una novedad resaltable de la Ley. No obstante, y debido a la distinta finalidad de unos y otros bienes, su régimen protector se distingue en los medios concretos de protección, dando prioridad a los bienes demaniales, debido a su consideración como de mayor importancia.

\section{Medios de protección}

Los medios de protección de los bienes públicos pueden agruparse a efectos expositivos de la siguiente forma:

\section{A) Limitaciones a la disponibilidad de los bienes ${ }^{46}$}

El art. 30-1. ${ }^{\circ}$, LPAP, reiterando lo establecido en el art. 132-CE, señala que "los bienes y derechos de dominio público o demaniales son inalienables, imprescriptibles e inembargables"; asignando a estos bienes sus tres características más importantes;

pp. 88-96; Jiménez Plaza, C., “La obligación de protección y defensa del patrimonio de las Administraciones Públicas”, en Mestre Delgado, J. F. (Dir.), y otros, obra citada, pp. 333-337; Moreu Carbonell, E., “El Derecho Público de los Bienes", op. cit., pp. 347-360, y Santamaría Pastor, J. A., "Principios de Derecho Administrativo General", obra citada, pp. 582-596.

45 Abajo Quintana J. J., "De la obligación de proteger y defender el patrimonio. Artículos 28 y 29", obra citada, pp. 397-399.

46 Ballesteros Moffa, L. A., "Protección y defensa del patrimonio: obligación administrativa, cooperación y límites de disponibilidad”, en Chinchilla Marín, C. (Coord.), y otros, obra citada, pp. 218-244, e "Inalienabilidad, inembargabilidad e imprescriptibilidad del dominio público", en González García, J. V. (Dir.), y otros, “Diccionario de Obras Públicas y Bienes Públicos”, Ed. lustel, Madrid, 2007, pp. 388-398; González García, J. V., “Notas sobre el régimen general del dominio público”, en González García, J. V. (Dir.), y otros, “Derecho de los Bienes Públicos”, obra citada, pp. 80-82; Moreu Carbonell, E., “El Derecho Público de los Bienes”, op. cit., pp. 348-351, y Santamaría Pastor, J. A., "Principios de Derecho Administrativo General", obra citada, pp. 593-596. 
siguiendo los cauces históricos (como hacía el art. 1271 del Código Civil, al establecer que "pueden ser objeto de contrato todas las cosas que no están fuera del comercio de los hombres").

En relación a las tres características, la inalienabilidad supone la imposibilidad de realizar enajenación alguna sobre dichos bienes y derechos, que constituye una condición intrínseca de los mismos que deriva de la afectación de los mismos a un uso general o al servicio público, precisamente para proteger ese destino de los bienes. Habitualmente, en la inalienabilidad se integra asimismo la imposibilidad de expropiar los bienes demaniales, de acuerdo con el art. 1-LEXF, al referirse únicamente a la propiedad privada ${ }^{47}$.

A diferencia de los anteriores, los bienes y derechos patrimoniales sí pueden ser enajenados, siguiendo el procedimiento y cumpliendo los requisitos legalmente establecidos (art. 30-2. ${ }^{\circ}$, LPAP).

Seguidamente, y también reiterando lo previsto en el art. 132-CE, se prevé la regla de la inembargabilidad de los bienes demaniales en el art. 30-1. ${ }^{\circ}$, LPAP, por la que estos bienes no pueden ser objeto de traba ni enajenación forzosa para el pago de deudas, sea judicial o administrativa.

Esta regla no es únicamente característica de los bienes demaniales sino que es un privilegio general y tradicional de la Hacienda Pública, aplicable a todos sus bienes y derechos, que se recogía en la Ley General Presupuestaria y en la Ley de Haciendas Locales, ambas de 1988. Formulación que fue objeto de críticas por su extensa amplitud. Recurrida la Ley de Haciendas Locales en este sentido, la STC 166/1998, de 15 de julio entendió que eran posibles los embargos de los bienes patrimoniales no afectados materialmente a un uso o servicio público. Doctrina que se plasma ahora en el art. 30-3. ${ }^{\circ}$, LPAP, así como en la Ley de Haciendas Locales de 2004 (art. 173-2. $)$ y en la Ley General Presupuestaria de 2003 (art. 23).

En relación con la doctrina de esta Sentencia constitucional, es interesante mencionar la STS de 19 de diciembre de 2001 (AR. 9946) porque enmarca la misma en un proceso de debilitamiento de las facultades de la Administraciones públicas para proteger sus propios bienes, al señalar que

“En el sustrato jurídico-conceptual de esta declaración, que introduce una fisura destacada en el régimen jurídico de una de las dos categorías bajo las cuales convencionalmente se han clasificado los bienes públicos, no es difícil intuir un notable debilitamiento de la intensidad con que la Administración puede autoproteger sus bienes privados sin necesidad de acudir al juez civil como el resto de los propietarios. Pues si estos bienes patrimoniales pueden ser embargados y ejecuta-

47 Santamaría Pastor, J. A., “Principios de Derecho Administrativo General”, obra citada, pp. 593594. 
dos en paridad con los de los particulares, la justificación última del resto de prerrogativas exorbitantes del régimen común que aún subsisten respecto de ellos queda ciertamente debilitada" (FJ n. $\left.{ }^{\circ}\right)^{48}$.

Finalmente, los bienes de dominio público son imprescriptibles, es decir las Administraciones Públicas no pueden perder su titularidad en virtud de usucapión o prescripción adquisitiva realizada por un tercero; rasgo que es uno de los más clásicos de estos bienes, que ya establecía el art. 1936 del Código Civil, y que en la actualidad, siguiendo lo establecido en el art. 132-CE, se prevé en el art. 30-1. ${ }^{\circ}$, LPAP.

Más en general, el art 31-LPAP no permite transacción judicial ni extrajudicial sobre los bienes y derechos del Patrimonio del Estado, ni someter a arbitraje las contiendas que se susciten sobre los mismos (si no es mediante Real Decreto del Consejo de Ministros, a propuesta del de Hacienda, con dictamen previo del Consejo de Estado).

\section{B) Publicidad posesoria y régimen registral}

La exigencia a la Administración pública de la obligación de llevar un registro documental, y completo, de todos sus bienes no ha existido durante mucho tiempo, quizás debido al carácter ostensible de la existencia, al menos, de los bienes demaniales. No obstante, tal obligación comenzará a exigirse en relación a bienes cuya titularidad podía ser problemática y conflictiva (como los montes públicos desde las Leyes del siglo XIX).

Actualmente, esta obligación se establece claramente en el art. 32-1. ${ }^{\circ}$, LPAP (que tiene carácter básico), al señalar que "las Administraciones públicas están obligadas a inventariar los bienes y derechos que integran su patrimonio, haciendo constar, con el suficiente detalle, las menciones necesarias para su identificación y las que resulten necesarias para reflejar su situación jurídica y el destino o uso a que están siendo dedicados" $"$.

En relación con el Estado, la propia LPAP crea y regula el Inventario General de Bienes y Derechos del Estado, como instrumento que integra todos los bienes y derechos del Patrimonio del Estado (arts. 32 a 35). Instrumentos similares se regulan en la legislación autonómica y local, así como en la legislación sectorial correspondiente.

48 A propósito de esta Sentencia, Moreu Carbonell, E., “Desmitificación, privatización y globalización de los bienes públicos: del dominio público a las <obligaciones de dominio público>”, Revista de Administración Pública, n. $161 / 2003$, pp. 435-477, realiza una reflexión sobre la crisis del Estado Social de Derecho y la "mitificación del mercado"; incluyendo comentarios sobre la Sentencia constitucional mencionada.

49 Sobre el inventario de los bienes públicos, vid. Fernández Rodríguez, C., "Inventario de bienes”, en González García, J. V. (Dir.), y otros, “Diccionario de Obras Públicas y Bienes Públicos”, Ed. lustel, Madrid, 2007, pp. 431-444, e "Inventario patrimonial y régimen registral”, en Chinchilla Marín, C. (Coord.), y otros, obra citada, pp. 291-313; Moreu Carbonell, E., “El Derecho Público de los Bienes”, op. cit., pp. 351-353, y Santamaría Pastor, J. A., "Principios de Derecho Administrativo General”, obra citada, pp. 584-585. 
Por otra parte, la inscripción registral ${ }^{50}$ no era exigible (aunque no de forma clara) conforme a la Legislación hipotecaria de 1946 y 1947. Posteriormente la Legislación de los años noventa del pasado siglo (Reglamento Hipotecario de 1998), prevé que los bienes demaniales podrán ser objeto de inscripción conforma a su legislación especial. En la actualidad, el art. 36-1., LPAP (con el carácter de básico), establece que "las Administraciones públicas deben inscribir en los correspondientes registros los bienes y derechos de su patrimonio, ya sean demaniales o patrimoniales, que sean susceptibles de inscripción, así como todos los actos y contratos referidos a ellos que puedan tener acceso a dichos registros"; siendo potestativa la inscripción de los arrendamientos. Regulándose la inscripción en los arts. 36-40, LPAP.

\section{c) Facultad de investigación}

Además de las reglas e instrumentos anteriores, y de acuerdo con la obligación general de proteger y defender su patrimonio para evitar su pérdida o usurpación, o para mantener las características de los bienes, su destino público y su uso adecuado al interés general y al Ordenamiento, el art. 41-LPAP reconoce diversas facultades y prerrogativas de las Administraciones Públicas para la defensa del mismo, como son investigar la situación de los bienes y derechos que presumiblemente pertenezcan a su patrimonio; deslindar en vía administrativa los inmuebles de su titularidad; recuperar de oficio la posesión indebidamente perdida sobre su bienes y derechos, y desahuciar en vía administrativa a los poseedores de los inmuebles demaniales, una vez extinguido el título que amparaba la tenencia; siendo posible también la adopción de medidas cautelares, una vez iniciado el procedimiento para el ejercicio de las facultades y potestades señaladas con la finalidad de asegurar la eficacia del acto que en su momento pueda dictarse, de acuerdo con la Ley de Procedimiento Administrativo Común (art. 42-LPAP, que tiene carácter básico) ${ }^{51}$.

50 En relación con el registro de estos bienes, vid. en general y sobre el régimen jurídico de la época, vid. Parejo Gamir, R., “Protección registral y dominio público”, Ed. EDERSA, Madrid, 1975. Sobre el régimen actual, ver Fernández Rodríguez, C., "Registro de bienes del patrimonio de las Administraciones Públicas”, en González García, J. V. (Dir.), y otros, "Diccionario de Obras Públicas y Bienes Públicos", obra citada, pp. 646-652, e “Inventario patrimonial y régimen registral”, en Chinchilla Marín, C. (Coord.), y otros, obra citada, pp. 313-322; Moreu Carbonell, E., "El Derecho Público de los Bienes”, obra citada, pp. 351-353, y Santamaría Pastor, J. A., “Principios de Derecho Administrativo General”, obra citada, pp. 584-585.

51 Sobre este precepto y las prerrogativas en general, vid. Marina Jalvo, B., “Facultades y prerrogativas para la defensa de los patrimonios públicos (artículo 41)”, en Mestre Delgado, J. F. (Dir.), y otros, "El Régimen Jurídico del Patrimonio de las Administraciones Públicas (Comentario a la Ley 33/2003, de 3 de noviembre)”, Ed. El Consultor, Madrid, 2004, pp. 435-454, y Carrillo Donaire, J. A., “Facultades y prerrogativas para la defensa de los Patrimonios Públicos. La investigación. El deslinde”, en Chinchilla Marín, C. (Coord.), y otros, “Comentarios a la Ley 33/2003, del Patrimonio de las Administraciones Públicas", obra citada, pp. 323-369. En relación con los bienes patrimoniales, específicamente, vid. González Bustos, M. ${ }^{\text {A }}$., “Defensa de los bienes patrimoniales", en Varios Autores, "El Derecho Administrativo en el umbral del si474 glo XXI. Homenaje al Prof. Dr. D. Ramón Martín Mateo”, Tomo III, Ed. Universidad de Alicante-Generalidad Valenciana-Ed. Tirant Lo Blanch, Valencia, 2000, pp. 2153-2169 
De forma sistemática, y no como a cualquier otro propietario ni con los mismos instrumentos (ya que los que pueden utilizar los particulares son mucho más limitados, y corresponden a los jueces) ${ }^{52}$, las Administraciones tienen la facultad de investigar la situación de los bienes y derechos que presumiblemente formen parte de su patrimonio, a fin de determinar la titularidad de los mismos cuando esta no conste de modo cierto (art. 45-LPAP, que tiene carácter básico); regulándose en la propia Ley el régimen y el procedimiento en la Administración General del Estado, incluido el premio por denuncia, para incentivar la participación de particulares en la defensa de estos bienes (arts. 46 a 49) (53 $^{\text {. }}$

\section{D) Deslinde}

A continuación, y también de forma privilegiada respecto a los particulares, los cuales gozan de esta posibilidad ex art. 384 del Código Civil, aunque deben acudir a los jueces para deslindar su propiedad de las colindantes, se reconoce a las Administraciones Públicas la potestad de deslindar ${ }^{44}$ sus bienes inmuebles, sean demaniales o patrimoniales, pero como decimos a diferencia de los particulares, éstas tienen la prerrogativa de fijar unilateralmente la extensión y los límites de sus bienes en caso de imprecisión o indicios de usurpación, delimitándolos frente a los contiguos sin intervención judicial, mediante un procedimiento administrativo de deslinde que finaliza con un acto ejecutivo y ejecutorio que se presume válido, trasladando la carga de la impugnación a los propietarios colindantes, y que no puede paralizarse mediante interdictos.

Así lo establece el art. 50-LPAP, con el carácter de básico, señalando que "las Administraciones Públicas podrán deslindar los bienes inmuebles de su patrimonio de otros pertenecientes a terceros cuando los límites entre ellos sean imprecisos o existan indicios de usurpación"; y añadiendo que "una vez iniciado el procedimiento administrativo de deslinde, y mientras dure su tramitación, no podrá instarse procedimiento judicial con igual pretensión"; regulándose el procedimiento de deslinde en el ámbito de la Administración General del Estado en los arts. 51 a 54-LPAP.

\section{E) Facultad de recuperación posesoria}

Esta facultad supone que las Administraciones Públicas, por sí mismas, pueden unilateralmente recuperar la posesión de sus bienes usurpados ${ }^{55}$, sin necesidad de acudir a

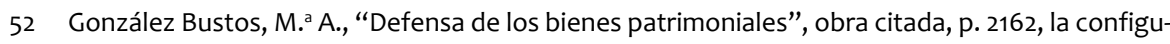
ra como una acción de investigación previa al ejercicio de la potestad de recuperación de de oficio y de la potestad de deslinde.

53 Carrillo Donaire, J. A., obra citada, pp. 354-360; Rodríguez González, M. a del P., “Potestad de investigación”, en González García, J. V. (Dir.), y otros, “Diccionario de Obras Públicas y Bienes Públicos”, obra citada, pp. 583-595

54 Sobre el régimen vigente, vid. Carrillo Donaire, J. A., obra citada, pp. 360-369; Rodríguez González, M. a del P., “Deslinde administrativo”, en González García, J. V. (Dir.), y otros, “Diccionario de Obras Públicas y Bienes Públicos", obra citada, pp. 285-297.

55 Agirreazkuenaga Zigorraga, I., "La recuperación de la posesión de los bienes y derechos del patrimonio. El desahucio", en Chinchilla Marín, C. (Coord.), y otros, “Comentarios a la Ley 33/2003, del Pa- 
los órganos judiciales, a diferencia de lo que ocurre en el ámbito privado. En efecto, el art. 55-LPAP, con el carácter de básico, establece que "las Administraciones Públicas podrán recuperar por sí mismas la posesión indebidamente perdida sobre los bienes y derechos de su patrimonio"; con una importante diferencia en función de la categoría de los bienes y derechos (y que resalta la trascendencia de unos y otros), ya que en el supuesto de bienes demaniales la potestad de recuperación no tiene plazo para ejercitarse y en el caso de los bienes patrimoniales el procedimiento de recuperación de la posesión ha de iniciarse en el plazo de un año, a contar desde el día siguiente al de la usurpación, y pasando este plazo deben utilizarse ya las acciones pertinentes ante la jurisdicción civil.

Lo órganos competentes de la Administración General del Estado y el procedimiento aplicable se regulan en los arts. 56 y 57-LPAP, sin el carácter de básicos, y con referencia expresa al desalojo del usurpador por la fuerza y a la imposición de multas coercitivas, en su caso, de acuerdo con la Ley de Procedimiento Administrativo Común.

\section{F) Desahucio administrativo}

Una manifestación de la recuperación de oficio de los bienes usurpados, y de la ejecución forzosa de los correspondientes actos administrativos, es el desahucio administrativo ${ }^{56}$, mediante el que "las Administraciones públicas podrán recuperar en vía administrativa la posesión de sus bienes demaniales cuando decaigan o desaparezcan el título, las condiciones o las circunstancias que legitimaban su ocupación por terceros" (art. 58-LPAP, que tiene carácter básico), presuponiendo pues una autorización previa del uso y aprovechamiento del bien demanial a otro sujeto (STS de 21 de junio de 2000, AR. 6719); regulándose el ejercicio de la potestad de desahucio y los órganos competentes (arts. 59 y 60-LPAP, que no tienen carácter básico), y dado el carácter ejecutivo del acto que pone fin al procedimiento, se incluye la posibilidad de utilizar la fuerza para el desalojo del usurpador y la posibilidad de imposición de multas coercitivas, de acuerdo con la Ley de Procedimiento Administrativo Común.

\section{G) Potestad de policía demonial}

La potestad de policía demanial57, como referencia global a las potestades administrativas singulares de defensa de estos bienes, incluyendo las sancionadoras, deri-

trimonio de las Administraciones Públicas”, obra citada, pp. 371-377, y “Defensa de los bienes públicos: Recuperación de la posesión de bienes y desahucio administrativo”, en González García, J. V. (Dir.), y otros, “Diccionario de Obras Públicas y Bienes Públicos”, Ed. lustel, Madrid, 2007, pp. 251-256.

56 Agirreazkuenaga Zigorraga, I., "La recuperación de la posesión de los bienes y derechos del patrimonio. El desahucio”, obra citada, pp. 377-384, y “Defensa de los bienes públicos: Recuperación de la posesión de bienes y desahucio administrativo”, obra citada, pp. 257-263.

57 Santamaría Pastor, J. A., "Principios de Derecho Administrativo General”, obra citada, p. 589. En general, y haciendo referencia a la imprecisión y amplitud del concepto ver Barcelona Llop, J., "Policía demo- 
va de la obligación general de las Administraciones Públicas de proteger y defender su patrimonio, previéndose para ello medidas de vigilancia y facultades de imposición de limitaciones de uso, zonas de protección y de servidumbres a los bienes colindantes, o a determinadas actividades, que se establecen en las leyes sectoriales reguladoras de los distintos bienes demaniales, así como la imposición de sanciones a quienes dañen tales bienes públicos.

\section{H) Protección penal de los bienes públicos}

Además de todas las medidas de protección de los bienes públicos anteriores, y sin perjuicio de la potestad sancionadora de la Administración, la trascendencia de los bienes públicos es visible asimismo porque cuentan con protección penal ${ }^{8}$.

No obstante, como es sabido, el Código Penal de 1995, modificado en 2010, no dedica una parte única y específica a la protección de estos bienes, sino que incluye diversas referencias a lo largo del texto. Así, a estos bienes se les aplican los preceptos relativos a los delitos contra el patrimonio (con algunas especialidades derivadas del carácter público de los mismos; Título XIII, "Delitos contra el patrimonio y contra el orden socioeconómico”, arts. 234 y ss.), seguidamente, el Código Penal prevé algunos tipos concretos en relación con el territorio, el patrimonio histórico y el medio ambiente (Título XVI, "De los delitos relativos a la ordenación del territorio y la protección del patrimonio histórico y del medio ambiente", arts. 319 y ss.), y finalmente también hay referencias a dicha protección en la regulación de los delitos contra la Administración Pública (Título XIX, “Delitos contra la Administración Pública”, arts. 404 y ss.).

\section{LA POTESTAD SANCIONADORA DE LA ADMINISTRACIÓN EN MATERIA DE BIENES PÚBLICOS}

El régimen jurídico de los bienes públicos establece como uno de sus ejes esenciales un sistema de especial protección de los mismos, dadas las finalidades que cumplen y su papel principal para que las Administraciones desarrollen sus funciones. Este sistema, que es común para los bienes demaniales y patrimoniales, salvo algunas peculiaridades de los primeros derivadas de su mayor trascendencia, de acuerdo con el art. 132-CE, se prevé, como hemos visto, con carácter general en los arts 1, 28 y 29LPAP, y se regula con cierto detalle en los arts. 30 a 64 de la misma Ley.

nial”, en González García, J. V. (Dir.), y otros, “Diccionario de Obras Públicas y Bienes Públicos”, Ed. lustel, Madrid, 2007, pp. 574-583. Más en concreto, Carrillo Donaire, J. A., "Servidumbres administrativas", en González García, J. V. (Dir.), y otros, “Diccionario de Obras Públicas y Bienes Públicos”, obra citada, pp. 659-676. 58 Ortiz de Urbina Gimeno, I., y Montaner Fernández, R., “Protección penal de los bienes públicos”, en González García, J. V. (Dir.), y otros, “Derecho de los Bienes Públicos”, 2. a ed., Ed. Tirant Lo Blanch, Valencia 2009, pp. 379-408, y Ortiz de Urbina Gimeno, I., "Protección penal de los bienes públicos”, en González García, J. V. (Dir.), y otros, “Diccionario de Obras Públicas y Bienes Públicos”, obra citada, pp. 605628. 
Junto a las medidas mencionadas, tanto las Leyes sectoriales relativas a bienes concretos, las Leyes regionales en materia de patrimonio y últimamente, lo que constituye una novedad destacable pues en la legislación anterior no había una regulación en la materia, la Ley de Patrimonio de las Administraciones Públicas ha regulado la potestad sancionadora en la materia (arts. 192 a 197); como otro de los instrumentos ordinarios para proteger los bienes públicos ${ }^{59}$. Además, el sistema jurídico de los bienes públicos, tanto general como sectorial, continúa utilizando la potestad sancionadora administrativa, siguiendo unos antecedentes históricos bien arraigados, y teniendo en cuenta la adecuación del sistema sancionador general al Texto Constitucional.

\section{Aspectos históricos de la potestad sancionadora de las Administraciones Públicas en materia de bienes públicos}

Sin necesidad de remontarnos más atrás en el tiempo, en la época medieval, Las Partidas del rey Alfonso X, redactadas en la mitad del siglo XIII, se dedican más a la titularidad de los ahora llamamos bienes públicos, y en su caso a no permitir su comercio; no conteniendo disposiciones sobre la protección de los mismos, y menos aún en materia sancionadora. Sin embargo, tanto el Fuero Real, de 1252-1255, como el Fuero Viejo de Castilla, de 1250, ya incluyen algunas multas para quienes cerraran y usurparan los caminos públicos; previendo además la obligación de los causantes de reparar los daños causados. Serán, no obstante, de forma ordinaria los Fueros y las Ordenanzas locales los textos que prevean disposiciones sobre la conservación de los bienes comunes, incluyendo la imposición de multas ${ }^{60}$.

Posteriormente, y sin perjuicio de otras disposiciones anteriores que no tuvieron una aplicación muy efectiva, las Ordenanzas del rey Fernando VI en materia de conservación de montes y plantíos, de 1748, junto a la anterior relativa a los montes de la Marina, señalan varias sanciones dinerarias y obligan a reparar los daños causados. Asimismo, en el siglo XVIII, existen disposiciones sancionadoras similares en materia de conservación y reparación de caminos (como la Cédula del rey Carlos III de 1762) y de aguas (como las Ordenanzas del buen gobierno y conservación de acequias de Valencia y Murcia) $)^{61}$.

59 Lozano Cutanda, B., “Infracciones y sanciones para la protección de los Bienes Públicos”, en González García, J. V. (Dir.), y otros, “Diccionario de Obras Públicas y Bienes Públicos”, obra citada, pp. 398399.

60 Font y Llovet, T., “La protección del dominio público en la formación del Derecho Administrativo Español: Potestad sancionadora y resarcimiento de daños”, obra citada, pp. 8-24; a quien seguimos. Asimismo, vid. Calvo del Pozo, J., "Potestad sancionadora e indemnización de daños y perjuicios al dominio público”, Revista Andaluza de Administración Pública, n. 40/2000, pp. 265-326. También, pero más en general, vid. el excelente trabajo de Martín-Retortillo Baquer, L., "Multas Administrativas", Revista de Administración Pública, n. ${ }^{\circ}$ 79/1976, pp. 9-65 (también publicado en la Nueva Enciclopedia Jurídica de Ed. Seix).

61 En este sentido, sobre la historia de la Legislación de Aguas, y su protección y la imposición de sanciones administrativas, ver Gallego Anabitarte, A., Menéndez Rexach, Á., y Díaz Lema, J. M., “El Derecho de Aguas en España", 2 tomos, Ed. MOPU, Madrid, 1986. 
Más adelante, la Legislación forestal incluirá una más detallada regulación sobre la policía y las contravenciones a la misma, así como sobre la reparación de los daños a los mismos; teniendo ya las autoridades administrativas una cierta importancia en la materia (p. ej., las Ordenanzas Generales de Montes de 1833 o las reformas de 1863 y 1884). Asimismo, la normativa de carreteras prevé ciertas prohibiciones de realizar obras en las mismas y fija las multas correspondientes (p. ej., las Ordenanzas para la Conservación y Policía de las Carreteras Generales de 1842). Sin embargo, la Ley de Aguas de 1866 dedica escasa atención a la protección de las mismas, remitiendo al Gobierno la regulación de las multas para los infractores; poca atención que reitera la Ley de Aguas de 1879, al hacer únicamente referencia a la policía de las aguas públicas y a la competencia de los Jurados de Riego para imponer correcciones a los infractores de las correspondientes Ordenanzas, que serán pecuniarias (más adelante, el Reglamento de Policía de Aguas de 1958 incluirá algunas sanciones en la materia). De igual forma, tampoco la Ley de Obras Públicas de 1877 incluye disposición sancionadora alguna.

Ya en el siglo XX, la Ley de Puertos de 1928 incluye una mención a las reglas de policía al regular el uso y aprovechamiento del mar litoral y de sus playas, y hace referencia a ciertas multas derivadas de desperfectos causados en las obras de un puerto por los buques o sus amarras, o si se produjese el ensuciamiento del mismo. Por su parte, la Ley de Pesca Fluvial de 1942 prevé alguna sanción y la obligación de reparar el daño producido. Sin embargo, el Reglamento de Bienes de las Entidades Locales de 1955 no incluye referencia alguna a la potestad administrativa sancionadora, confiando la defensa de los bienes locales a los instrumentos ya conocidos (inventario, deslinde, reivindicación de los bienes y desahucio, ex arts. 16 y ss.).

En esta época, el art. 27 de la Ley de Régimen Jurídico de la Administración del Estado de 1957 establece que las disposiciones administrativas "no podrán establecer penas"; planteándose si en este concepto pueden incluirse las multas administrativas, teniendo en cuenta que las Leyes relativas a algunos de los bienes públicos, remiten $\mathrm{y}$, en particular, las posteriores remitirán a las normas reglamentarias la concreción de las infracciones y sanciones en la materia, como veremos. La interpretación común en la época es que tal concepto no incluye las multas administrativas ${ }^{62}$, tal como señala la STS de 25 de junio de 1966 (AR 89, de 1967), al cuestionarse la legalidad del artículo 134 del Reglamento Taurino (aprobado por una mera Orden Ministerial de 15 de marzo de 1962), en base al cual se había puesto una multa a un ganadero de bravo, que señala

“...pero como este artículo es también impugnado en su totalidad por supuesta oposición con el artículo 27 en relación con los 23 y 26 de la Ley de Régimen Jurídico.../..., precisa antes de hacer lo primero, desvanecer totalmente tales supuestos de nulidad

62 En contra, Martín-Retortillo Baquer, L., “Multas Administrativas”, obra citada, pp. 38 y ss., al mantener que el concepto de "penas" de la Ley debe interpretarse en sentido amplio y genérico, en el que se integran con normalidad las multas administrativas. 


\begin{abstract}
del artículo 134 antes dicho, los que se hallan basados en la errónea creencia de que las multas administrativas son sanciones de naturaleza verdaderamente penal, como en efecto lo son las que imponen los juzgados y tribunales de la jurisdicción ordinaria o de las jurisdicciones especiales, por razón de delito o falta; pues, las de este grupo sí, y aquellas otras no necesitan de una Ley votada en Cortes para poderse imponer en sanción de hechos previamente definidos como delitos o faltas; pero en la Reglamentación administrativa de múltiples y variadas materias, que se hallan sometidas al cuidado y vigilancia de la Administración y en las que ésta actúa regladamente, en funciones de tutela y policía gubernativa, para intervenir acciones u omisiones de sus administrados que para nada rozan la materia penal o criminal propiamente dicha, es de todos los tiempos conocido y por todos los Estados de Derecho practicado, que las facultades en tal orden es de cosas reservadas a la Administración, permiten a ésta regular mencionadas actividades de orden público administrativo, imponiendo y exigiendo multas como sanción, como las que son objeto del Reglamento del Espectáculo taurino que nos ocupa, sin que tales sanciones tengan nada que ver con la prohibición contenida en el artículo 27 de la Ley de Régimen Jurídico, pues ni son dichas sanciones penas propiamente dichas ni revisten carácter fiscal de exacciones, tasas, cánones, derechos o cargas de naturaleza similar...".
\end{abstract}

Sentencia precedida por las de 11 y 15 de junio de 1966 y a la que siguen otras muchas en el mismo sentido (p. ej., la STS de 23 de junio de 1971, AR 3742, también en materia taurina).

Poco después de la Ley anterior, y de forma jurídicamente más adecuada y sistemática, la Ley de Montes de 1957 dedica ya su Título VI (arts. 81 a 87) a las infracciones y su sanción, previendo multas (con concreción reglamentaria de las infracciones y la cuantía de las sanciones, u otras medidas), una intervención preventiva de la Administración Forestal y la exigencia por esta misma de la responsabilidad por los daños causados. Asimismo, años más tarde, la Ley de Incendios Forestales de 1968 prevé un Título VI (arts. 30-34) sobre las infracciones y su sanción, reafirmando la competencia administrativa en la materia, la imposición de multas y la fijación reglamentaria de las faltas y la cuantía de las sanciones.

Más destacable es la ausencia de regulación de la potestad sancionadora en la materia en la Ley de Patrimonio del Estado de 1964, pues únicamente reguló (en el Capítulo VIII del Título I, relativo a la cooperación, arts. 48 a 53) las sanciones por el incumplimiento de la obligación de coadyuvar en la investigación, administración e inspección de los bienes y derechos de ese patrimonio, así como por negligencia o incumplimiento de las obligaciones de custodia, conservación, aplicación y racional explotación sobre las se prevé una clara competencia administrativa. Asimismo, años más tarde, la Ley de Incendios Forestales de 1968 prevé un Título VI (arts. 30-34) sobre las infracciones y su sanción, reafirmando la competencia administrativa en la materia, la imposición de multas y la fijación reglamentaria de las faltas y la cuantía de las sanciones. En parecido sentido, y en esta misma época, tampoco la Ley de Costas de 1969 incluye una regulación de la potestad sancionadora, previendo solamente la policía de moralidad, higiene y salubridad, y la vigilancia de la observancia de las instrucciones 480 correspondientes en los lugares de baño, que asigna a los Ayuntamientos (art. 17). 
Poco tiempo después, la Ley de Minas de 1973 contiene una escueta y poco precisa referencia a la potestad sancionadora, en su Título XIII, sobre competencia administrativa y sanciones (arts. 114-121), al prever la imposición de multas por la infracción de las prescripciones de la Ley y de su Reglamento, que no dé lugar a la caducidad de las autorizaciones de explotación, así como por la inobservancia de las prescripciones o condiciones de la Administración (no obstante, bastantes años después, en 2007, se modificará el art. 121 para regular adecuadamente las infracciones y sanciones en la materia). Asimismo, la Ley de Investigación y Explotación de Hidrocarburos de 1974 contiene una regulación similar (arts. 80 a 82).

Por su parte, la Ley de Autopistas en Régimen de Concesión de 1972 no contiene referencias a la potestad sancionadora administrativa en la materia, pero sí la Ley de Carreteras de 1974, en su Título III relativo a su uso y defensa, que prevé de forma poco precisa el régimen sancionador de las infracciones establecidas, así como, en su caso, la obligación de indemnizar los daños y perjuicios causados (art. 44).

La regulación de la incipiente potestad sancionadora administrativa en materia de bienes públicos, y teniendo en cuenta el Ordenamiento Jurídico de la época, se caracteriza por la escasez, imprecisión, generalidad y amplitud de de la regulación legal en la materia, la recurrente remisión a la potestad reglamentaria para llenar de contenido las infracciones y las sanciones en la materia, sin atender al principio de legalidad ni al de tipicidad, la práctica no aplicación del principio non bis in ídem y la gran discrecionalidad de la Administración para decidir si se inician o no los procedimientos sancionadores ${ }^{63}$.

\section{El régimen jurídico general en materia sancionadora}

La Constitución Española de 1978, como en tantos otros ámbitos, establece un nuevo marco jurídico, al más alto nivel, de la potestad sancionadora de las Administraciones Públicas ${ }^{64}$. A grandes rasgos, los aspectos más destacables de la regulación

63 Martín-Retortillo Baquer, L., “Multas Administrativas”, obra citada, pp. 21 y 22, y Santamaría Pastor, J. A., "Principios de Derecho Administrativo General”, obra citada, pp. 374-376.

64 En relación con el sistema sancionador administrativo derivado de la Constitución Española y vigente, y sin pretender agotar las obras, vid. Domínguez Vila, A., "Constitución y Derecho Sancionador", Ed. M. Pons, Madrid, 1997; Melón Muñoz, A., y Ruiz de Palacios Villaverde, J. I., y otros-Memento Práctico Francis Lefebvre, “Infracciones y Sanciones 2005-2006”, Ed. Francis Lefebvre, Madrid, 2005; Nieto, A., “Derecho Administrativo Sancionador”, 4. a ed., Ed. Tecnos, Madrid, 2005; Pemán Gavín, J., “El sistema sancionador español (Hacia una teoría general de las infracciones y sanciones administrativas)”, Ed. CEDECS, Barcelona, 2000; Rebollo Puig, M., Izquierdo Carrasco, M., Alarcón Sotomayor, L., y Bueno Armijo, A., "Panorama del Derecho Administrativo Sancionador en España. Los derechos y garantías de los ciudadanos", Estudios Socio-Jurídicos (Bogotá-Colombia), n. ${ }^{\circ}$ 7/2005, pp. 23-74; Sanz Gandasegui, F., "La potestad sancionadora de la Administración: la Constitución Española y el Tribunal Constitucional”, Ed. EDERSA, Madrid, 1985; Suay Rincón, J., "Sanciones administrativas", Studia Albornotiana, Bolonia, 1989, Santamaría Pastor, J. A., "Principios de Derecho Administrativo General”, obra citada, pp. 369-422, y Trayter Jiménez, J. M., y Aguado y Cudolá, V., "Derecho Administrativo Sancionador: materiales”, Ed. CEDECS, Barcelona, 1995. 
constitucional son la ratificación de esta potestad en los arts. 25-1. ${ }^{\circ}$ y $45-3 .^{\circ}$, la previsión de los principios de legalidad y tipicidad en el mismo art. $25-1 .^{\circ}$, e integrando en ellos el principio non bis in ídem, el principio de irretroactividad de las normas sancionadoras administrativas, la exclusión de sanciones administrativas que supongan la privación de libertad personal en el art. 25-3. ${ }^{\circ}$, la aplicación del principio de igualdad del art. 14 y la exigencia de las garantías del art. 24 en los procedimientos sancionadores de la Administración. Previsiones que han servido de base a una doctrina del Tribunal Constitucional que ha enmarcado el sistema sancionador administrativo completamente.

En relación con la distribución de competencias en materia sancionadora, la doctrina del Tribunal Constitucional permite a las Comunidades Autónomas su regulación cuando "teniendo competencia sobre la materia sustantiva de que se trate, tales disposiciones se acomoden a las garantías constitucionales dispuestas en este ámbito del Derecho Sancionador (art. 25-1 de la Constitución básicamente) y no introduzcan divergencias irrazonables y desproporcionadas al fin perseguido respecto del régimen jurídico aplicables en otras partes del territorio" (SsTC 87/1985, de 16 de julio, y $123 / 2003$, de 19 de junio) $)^{65}$.

Teniendo en cuenta lo anterior, y después de algún otro intento ${ }^{66}$, el régimen de la potestad sancionadora administrativa se establece en la Ley 30/1992, de 26 de noviembre, de Régimen Jurídico de las Administraciones Públicas y del Procedimiento Administrativo Común (BOE del 27), modificada en 1999, que, según su Exposición de Motivos, regula "los principios básicos a que debe someterse el ejercicio de la potestad sancionadora de la Administración y los correspondientes derechos que de tales principios se derivan para los ciudadanos extraídos del Texto constitucional y de la ya consolidada jurisprudencia sobre la materia". En efecto, de acuerdo con el art. 149-1. 18. ${ }^{\mathrm{a}-\mathrm{CE}}$ a efectos competenciales, en lo que se refiere al procedimiento administrativo común, la LRJ-PAC regula con carácter general la potestad sancionadora en su Título IX (arts. 127 a 138), estableciendo en dos Capítulos el régimen de los principios de la potestad sancionadora y del procedimiento sancionador; y regulando el marco general, sin referencias específicas a las infracciones y sanciones, ni a otras cuestiones concretas. Su desarrollo se ha producido mediante el Real Decreto 1398/1993, de 4 de agosto, que aprueba el Reglamento del procedimiento para el ejercicio de la Potestad Sancionadora (BOE del 9).

Seguidamente, las Leyes reguladoras de los diferentes ámbitos administrativos establecen de forma detallada el sistema de infracciones y sanciones, junto al resto de la regulación concreta, en cada uno de ellos.

65 Lozano Cutanda, B., “Infracciones y sanciones para la protección de los Bienes Públicos”, en González García, J. V. (Dir.), y otros, "Diccionario de Obras Públicas y Bienes Públicos”, obra citada, pp. 399-400, y “Régimen sancionador”, en Chinchilla Marín, C. (Coord.), y otros, “Comentarios a la Ley 33/2003, del Patrimonio de las Administraciones Públicas”, obra citada, p. 891.

66 Suay Rincón, J., “El Derecho Administrativo sancionador: perspectivas de reforma”, Revista de Administración Pública, n. ${ }^{\circ}$ 109/1986, pp. 185-215, analiza con detalle una Proposición de Ley en la materia de 1985 . 


\section{El sistema normativo de la potestad sancionadora en materia de bienes públicos}

De acuerdo con lo establecido en la Constitución Española, en general y a efectos competenciales, y teniendo en cuenta la regulación general de la potestad sancionadora en la LRJ-PAC, la Ley del Patrimonio de las Administraciones Públicas, como novedad destacable en relación con las Leyes anteriores, regula el régimen sancionador en su Título IX (arts. 192 a 197), para hacer frente a los incumplimientos de la misma y, en última instancia, para defender la integridad y proteger los bienes públicos. No obstante, estos preceptos no tienen el carácter, a efectos competenciales, de normas de aplicación general ni de normas básicas (DF-2. ${ }^{a}$, LPAP), por lo que tienen naturaleza supletoria de la legislación específica de las Comunidad Autónomas. Además debe tenerse en cuenta el sistema normativo general y competencial en materia de bienes (arts. 2, 5 y 7, y DF-2. a, LPAP), y en concreto la Legislación sectorial de cada uno de los bienes públicos, que contienen el régimen concreto de infracciones y sanciones en cada ámbito (aguas, carreteras, costas, etc.) ${ }^{67}$.

\section{El régimen de la potestad sancionadora en la Ley de Patrimonio de las Administraciones Públicas}

\section{A) La aplicación de los principios rectores, y del régimen general, del ámbito sancionador por la Ley de Patrimonio de las Administraciones Públicas y por la legislación sectorial sobre bienes concretos}

Con carácter general, la Jurisprudencia sostiene la teoría general del ilícito, incluyendo el penal y el administrativo, por lo que la potestad sancionadora de las Administraciones Públicas ha de ajustarse a ciertos principios rectores que se han elaborado en el ámbito penal, y que actualmente, la mayoría, tienen respaldo constitucional (SsTS de 23 de enero de 1989, AR. 421, y de 19 de noviembre de 2001, AR. 9791, entre otras). No obstante, su aplicación no es automática al ámbito administrativo, sino que deben resaltarse ciertas peculiaridades, tanto sustantivas como procedimentales y procesales, derivadas de las diferencias entre ambos sectores jurídicos (STC 76/1990, de 26 de abril, y STS de 19 de noviembre de 2001, AR. 9791 ${ }^{68}$. Principios que

67 Suárez Ferrín, M. a A., “Infracciones y sanciones”, en DE Fuentes Bardajía, J. (Dir.), y otros-Abogacía General del Estado (Dirección General del Servicio Jurídico del Estado), "Comentarios a la Ley de Patrimonio de las Administraciones Públicas", obra citada, pp. 1323-1393, reproduce la legislación nacional de carácter general y sectorial y la legislación autonómica correspondiente. Por su parte, Melón Muñoz, A., y Ruiz de Palacios Villaverde, J. I., y otros-Memento Práctico Francis Lefebvre, “Infracciones y Sanciones 2005-2006", obra citada, analizan la legislación nacional y la autonómica, en su caso, en relación con los bienes públicos concretos.

68 Lozano Cutanda, B., "Infracciones y sanciones para la protección de los Bienes Públicos", obra citada, pp. 401-409, y en general Melón Muñoz, A., y Ruiz de Palacios Villaverde, J. I., y otros-Memento Práctico Francis Lefebvre, "Infracciones y Sanciones 2005-2006”, obra citada, pp. 33-35; a quienes seguimos. 
son, naturalmente, asumidos por la LRJ-PAC, la LPAP y, especialmente, por la legislación reguladora de los bienes públicos concretos.

\section{a) Principios de legalidad y de tipicidad}

Previsto en el art. 25-CE y en la LRJ-PAC, el principio de legalidad supone la necesaria y previa fijación normativa de las infracciones y sanciones administrativas, precisamente en la legislación vigente en aquel momento (SsTC 276/2000, de 16 de noviembre, $113 / 2002$, de 19 de mayo, 100/2003, de 2 de junio, y 9/2006, de 16 de enero, entre otras); concepto este último que hace referencia a una reserva de ley en materia sancionadora administrativa, si bien el alcance de la misma en el ámbito administrativo no puede ser tan riguroso como lo es en el ámbito penal (por ser necesaria una rápida variación de criterios de regulación o por razones de prudencia y oportunidad), por lo que no se excluye la posibilidad que las leyes contengan remisiones a normas reglamentarias siempre que en las primeras queden suficientemente precisados los elementos de la infracción y la naturaleza y los límites de las sanciones (STC 101/1988, de 8 de junio).

Por su parte, el principio de tipicidad de infracciones y sanciones deriva del anterior necesariamente, y supone que la predeterminación normativa de las mismas no puede hacerse de cualquier forma sino que esa legislación debe ser lo suficientemente precisa para que pueda conocerse con claridad la conducta ilícita y la sanción aplicable; es decir, que la norma permita predecir con suficiente grado de certeza las conductas que constituyen infracción y el tipo y grado de sanción a imponerse (STC 113/2002, de 19 de mayo).

La LPAP, en sus arts. 192 y 193, cumple las exigencias constitucionales en relación con estos principios y con la doctrina jurisprudencial referida, en los que se establecen las infracciones en la materia y las sanciones consecuentes, con suficiente certeza en ambos casos.

En cuanto a las infracciones (art. 192), las mismas se clasifican en leves, graves y muy graves, en función de su naturaleza y del daño producido, y sin hacer ninguna remisión reglamentaria. En relación con todas ellas, puede resaltarse que la gran mayoría tiene relación con los bienes de dominio público, ya que únicamente las infracciones relativas al incumplimiento de los deberes de comunicación y de colaboración previstos en los arts. 18 y 61 a 63-LPAP (deber de comunicar saldos y depósitos abandonados y los de colaboración del personal al servicio de las Administraciones Públicas, de los ciudadanos y de Notarios y Registradores) se aplican a todos los bienes públicos, demaniales o patrimoniales; frente a la gran mayoría de las Leyes regionales en la materia que hacen referencia a ambos tipos de bienes. Esta exclusión de la Ley nacional puede justificarse en la trascendencia esencial de estos bienes en el funcionamiento de las Administraciones Públicas y en el goce de los bienes o del uso de servicios públicos por los ciudadanos, aunque la misma no encaja muy bien en el es-

484 quema común de protección de todos los bienes públicos asumido en la propia Ley, 
como hemos visto; el cual, por cierto, constituye una de las novedades más destacables del texto ${ }^{69}$. Por su parte, las Leyes sectoriales relativas a los bienes concretos recogen las infracciones y sanciones, en algunos de los ámbitos con remisiones reglamentarias (p. ej., aguas, costas, carreteras o minas).

Por lo que se refiere a las sanciones, la LPAP (art. 193) utiliza la más común, que es la de carácter pecuniario, la multa, en función de la gravedad de la infracción, atendiéndose para graduarla a los daños causados, al valor de los bienes o derechos afectados, a la reiteración del responsable y al grado de culpabilidad del mismo, considerándose que la corrección por el infractor de la situación creada por la infracción, en el plazo que se le señale, permitirá reducir la multa hasta la mitad. Además, se prevé una multa periódica para el supuesto de retrasos en el cumplimiento del deber de comunicación de saldos y depósitos abandonados, con cierta semejanza con las multas coercitivas de la LRJ-PAC (art. 99), previstas como medio de ejecución forzosa de los actos administrativos, pero que en el caso de la LPAP no puede considerarse como tal pues se tipifica claramente como una sanción, precisamente la correspondiente, excluyendo cualquier otra, al incumplimiento referido, que ya se ha producido, y que ha debido constatarse jurídica y procedimentalmente con carácter previo ${ }^{70}$; es más, la propia LPAP prevé las multas coercitivas para la ejecución forzosa en su art. 197-2. De acuerdo con la doctrina ya señalada, también en relación con la tipificación de las sanciones se permite, en la legislación sectorial sobre los bienes (así, aguas o carreteras), la precisión de las mismas mediante remisiones reglamentarias.

Además, el mismo art. 193-LPAP prevé la inhabilitación del infractor para ser titular de autorizaciones y concesiones, por un plazo de uno a tres años, en caso de reincidencia en infracciones graves y muy graves. Previsión que también se establece en la legislación sectorial sobre los bienes concretos (p. ej., costas o ferrocarriles).

En relación con las sanciones, y la necesidad de certeza en su predeterminación, es importante resaltar que no caben las mismas cuando, respecto a un bien concreto, no se haya llevado a cabo el deslinde correspondiente de forma completa, debido a que antes de realizarse el mismo "existe una situación territorialmente indefinida que impide a la Administración adoptar esas medidas [de recuperación y sancionadoras] por venir sometidas al principio de legalidad, incompatible con esta indefinición"71.

69 Así se expresa con claridad Lozano Cutanda, B., "Infracciones y sanciones para la protección de los Bienes Públicos”, obra citada, pp. 411-413, y “Régimen sancionador”, obra citada, pp. 897-899.

70 Así se expresan Lozano Cutanda, B., "Infracciones y sanciones para la protección de los Bienes Públicos”, obra citada, pp. 415-416, y “Régimen sancionador”, obra citada, p. 901, y Suárez Ferrín, M. ${ }^{a}$ A., "Infracciones y sanciones", obra citada, pp. 1358-1359. Por su parte, Trayter Jiménez, J. M., "Régimen sancionador", en Mestre Delgado, J. F. (Dir.), y otros, “El Régimen Jurídico del Patrimonio de las Administraciones Públicas (Comentario a la Ley 33/2003, de 3 de noviembre)”, Ed. El Consultor, Madrid, 2004, pp. 1321-1323, estima que nos encontramos ante una multa coercitiva "para obligar al afectado a realizar dicha imposición legal".

71 STS de 12 de abril de 1985, tomada de Lozano Cutanda, B., "Infracciones y sanciones para la protección de los Bienes Públicos”, obra citada, pp. 403-404, que cita alguna más en el mismo sentido. 
Por otra parte, la LPAP (art. 197), entre las cuestiones procedimentales, remite la ejecución de las sanciones y el cumplimiento de otras obligaciones contraídas a los medios de ejecución forzosa previstos en la LRJ-PAC, a los previstos pues en los arts. 96 a 100, es decir el apremio sobre el patrimonio, la ejecución subsidiaria, la multa coercitiva y la compulsión sobre las personas; aunque se fijan algunos límites a las multas coercitivas (no superar el $20 \%$ de la sanción u obligación y no podrán reiterarse en plazos inferiores a ocho días). Estas formas de garantizar la ejecución de las sanciones se recogen asimismo, aunque en algunos casos no se mencionan todos los medios, en las Leyes reguladoras de los bienes concretos (como aguas, costas o puertos).

De forma ordinaria, y siguiendo la LRJ-PAC en cuanto a los plazos concretos, el art. 194-LPAP establece la prescripción ${ }^{72}$, extinguiendo la responsabilidad correspondiente, de las infracciones y sanciones, sin novedades. Previsión legal que también acogen las Leyes sectoriales reguladoras de los bienes, aunque con otros plazos de acuerdo con el carácter mínimo y supletorio de lo regulado en la LRJ-PAC (como en materia de carreteras, costas, ferrocarriles o puertos).

Con independencia de la imposición de las sanciones correspondientes, y como medida complementaria, el art. 193-3. ${ }^{\circ}$, LPAP, obliga al infractor a restituir y reponer los bienes a su estado anterior, indemnizando de los daños irreparables y perjuicios causados (a la Administración o a los bienes y servicios públicos correspondientes); medida especialmente importante dada la trascendencia de los bienes públicos, en especial los demaniales, para las Administraciones Públicas y el desempeño de sus funciones. Y por esta razón, se prevé de forma ordinaria en la legislación sectorial sobre los bienes concretos (así, aguas, carreteras, costas, montes o puertos).

\section{b) Principio non bis in idem}

Estrechamente ligado a los anteriores, y al principio de seguridad jurídica (SsTS de 6 de mayo de 1987, AR. 3276, y de 23 de diciembre de 1992, AR. 10111), aunque sin base constitucional directa, pero derivado inexcusablemente del art. 25-CE (SsTC 2/1981, de 30 de enero, 77/1983, de de 3 de octubre, y 159/1985, de 27 de noviembre), este principio ${ }^{73}$ impide una doble sanción penal y administrativa, así como la duplicidad de las administrativas, por los mismos hechos a un mismo sujeto, es decir, tal como prescribe el art. 133-LRJ-PAC, que "no podrán sancionarse los hechos que hayan sido sancionados penal o administrativamente, en los casos en que se aprecie identidad del sujeto, hecho y fundamento", de acuerdo con una consolidada doctrina constitucional. Además, desde el punto de vista procesal, el principio impide asimismo la apertura de dos procedimientos, penal y administrativo, simultáneamente por

72 Lozano Cutanda, B., “Régimen sancionador”, obra citada, pp. 920-923.

73 Lozano Cutanda, B., "Infracciones y sanciones para la protección de los Bienes Públicos”, obra 
los mismos hechos; dándose prioridad en todo momento a la jurisdicción penal frente al procedimiento sancionador administrativo (tal como refleja el art. 7 del Real Decreto 1398/1993, de 4 de agosto que aprueba el Reglamento del Procedimiento para el ejercicio de la Potestad Sancionadora, BOE del 9). Principio que se recoge expresamente en la legislación sectorial de los bienes concretos (como aguas, costas, carreteras o montes).

\section{c) Principio de culpabilidad}

Procedente del ámbito penal (nulla poena sine culpa), el principio de culpabili$\mathrm{dad}^{74}$ supone que toda responsabilidad derivada de la infracción cometida ha de ser imputable a su autor, a título de dolo, culpa o negligencia, y es recogido, teniendo en cuenta las particularidades de su aplicación al ámbito administrativo, como la responsabilidad de las personas jurídicas y la responsabilidad solidaria (reconocidas por la STC 76/1990, de 14 de abril), en el art. 130-1. ${ }^{\circ}$, LRJ-PAC, y consolidado por la jurisprudencia (STC 76/1990, de 14 de abril, y SsTS de 9 de junio de 1986, AR. 6612, y 13 de octubre de 1989, AR. 8396, entre otras). Habitualmente, en este principio se integra el de antijuridicidad, que hace referencia al conocimiento que el inculpado posee del hecho generador de la infracción, es decir que tenga la conciencia de que tal hecho es contrario al Ordenamiento (SsTS de 14 de junio de 1989, AR. 4625, y de 12 de marzo de 1990, AR. 3155, entre otras).

Este principio se asume en la LPAP (art. 193), como es visible, al regular la graduación de la cuantía de las multas, los efectos de la reincidencia en la infracción y las circunstancias del infractor para reducir la multa. Por su parte, la legislación sectorial sobre los bienes concretos recoge aspectos concretos que asumen el principio citado (p. ej., costas y montes).

\section{d) Otros principios aplicables}

Además de los anteriores, que sin duda son los más importantes, en el ámbito sancionador rigen asimismo otros principios de carácter general ${ }^{75}$, que naturalmente se recogen en la Constitución Española y en la legislación sancionadora de carácter general, aplicándose por ello al ámbito sancionador de los bienes públicos.

Entre estos, podemos destacar el principio de irretroactividad (prohibición de la retroactividad de las normas sancionadoras no favorables o restrictivas de dere-

74 Lozano Cutanda, B., "Infracciones y sanciones para la protección de los Bienes Públicos”, obra citada, pp. 404-409, y “Régimen sancionador”, obra citada, pp. 904-909.

75 Melón Muñoz, A., y Ruiz de Palacios Villaverde, J. I., y otros-Memento Práctico Francis Lefebvre, “Infracciones y Sanciones 2005-2006”, obra citada, pp. 33-108, que analizan todos los principios aplicables al ámbito sancionador administrativo. 
chos individuales, impidiendo que el ciudadano sea sorprendido con posterioridad a su conducta con una calificación sancionadora no prevista o más grave que la fijada en el momento de la realización del hecho ilícito, STS 28 de mayo de 1990, AR. 4397).

También debemos citar el principio de presunción de inocencia, que, como es bien sabido, hace referencia a la suposición de no existencia de la responsabilidad correspondiente mientras no existan pruebas en tal sentido, impidiendo la sanción sin esta previa actividad probatoria (STC 76/1990, de 14 de abril); actividad que ha de cumplir las previsiones de la legislación sancionadora de carácter general, como garantía de su fiabilidad.

Asimismo, deben mencionarse, como aplicables al ámbito sancionador, los principios de seguridad jurídica, especialidad, prohibición de las reformas que empeoran la situación (reformatio in peius), interpretación más favorable de las normas, contradicción o acusatorio y principio in dubio pro reo.

\section{B) Aspectos procedimentales}

En materia procedimental, obviamente, al ámbito sancionador en materia de bienes públicos se le aplican las garantías derivadas de la propia Constitución Española y asumidas por la doctrina constitucional (SsTC 18/1981, de 8 de junio, y 77/1983, de 3 de octubre). Estas garantías se establecen en la LRJ-PAC (arts. 134 a 138, que se aplican a todas las Administraciones Públicas, ex arts 1 y 2), y hacen referencia a la garantía de procedimiento (establecimiento legal o reglamentario del procedimiento; debida separación de las fases instructora y sancionadora e imposibilidad de imponer una sanción sin procedimiento), derechos del presunto responsable (derecho de notificación de los hechos, infracciones y sanciones, identidad del instructor, de la autoridad sancionadora y norma competencial, derecho a formular alegaciones y a utilizar medios de defensa, así como los derechos generales del art. 35-LRJ-PAC), aplicación de medidas de carácter provisional según la legislación aplicable, presunción de inocencia y resolución.

No obstante, debe tenerse en cuenta la legislación aplicable en materia de bienes públicos, ya que la LRJ-PAC, como es sabido, no regula propiamente el procedimiento sancionador, sino que únicamente establece los principios generales y más importantes en la materia, desarrollándose los mismos y regulándose tales procedimientos, de acuerdo con la Disp. Ad. $3 .{ }^{\text {a }}$ de la Ley, y concretamente en la materia referida en el Reglamento de Procedimiento de la Potestad Sancionadora de 1993, ya mencionado, si bien el mismo rige "en defecto total o parcial de procedimientos específicos previstos en las correspondientes normas”, previendo su aplicación por la Administración General del Estado en materias en que el Estado tenga la competencia exclusiva y por las Administraciones de las Comunidades Autónomas y las

488 Administraciones Locales en las materias en que el Estado tenga competencia nor- 
mativa plena (art. 1); debiendo, pues, aplicarse la normativa sancionadora correspondiente de las Comunidades Autónomas en los supuestos de competencia material propia.

De acuerdo con el marco anterior, y con el sistema general de distribución de competencias, para la imposición de las sanciones correspondientes la LPAP se remite completamente al Reglamento del Procedimiento Sancionador de 1993 (art. 196). Seguidamente, las Leyes regionales reguladoras del Patrimonio propio pueden establecer y regular, incluso con desarrollo reglamentario, el procedimiento correspondiente, aplicándose supletoriamente la norma citada. Por su parte, la legislación sectorial relativa a los bienes públicos ha regulado el procedimiento sancionador completamente (p. ej., en materia de aguas) y en otros supuestos se remite al Reglamento mencionado, introduciendo algunas peculiaridades.

En relación con el procedimiento sancionador la LPAP incluye, en primer término, unas breves disposiciones sobre los órganos de la Administración General del Estado competentes en materia sancionadora (art. 195, que asigna las mismas al Consejo de Ministros, al actual Ministro de Economía y Hacienda y a los restantes Ministros o presidentes o directores de los Organismos Públicos, en función del importe de las sanciones y su gravedad; previsiones competenciales que también incluyen las Leyes reguladoras de los bienes públicos concretos), y, seguidamente, como sabemos, se remite al Reglamento del Procedimiento Sancionador, sin ninguna singularidad, por lo que únicamente se expondrán las particularidades del mismo aplicables al ámbito sancionador de los bienes públicos ${ }^{76}$.

Sobre la base de las fases clásicas del procedimiento sancionador (iniciación, instrucción y resolución), la iniciación del procedimiento sancionador en materia de bienes públicos es normalmente de oficio, debido a la trascendencia de los mismos para las Administraciones Públicas; siendo en este punto destacable el deber de colaboración en la protección, defensa y administración de los bienes y derechos de los patrimonios públicos establecido en el art. 61-LPAP (cuyo incumplimiento constituye una infracción grave, ex art. 192); siendo posible que el órgano competente realice las adecuadas funciones de investigación en relación con la situación, para precisar los hechos y situaciones concretas. Con todo ello, este órgano adoptará el acuerdo de iniciación del procedimiento sancionador, cuyo contenido, especialmente importante, ha de incluir la identificación de la persona responsables, los hechos que motivan el procedimiento, su valoración jurídica provisional y las posibles sanciones aplicables, así como los datos de identidad relativos al instructor del procedimiento, secretario y órgano resolutorio; notificándose el mismo al inculpado, al denunciante, en su caso, a los interesados y al órgano competente para la instrucción del mismo.

76 Seguimos el detallado análisis de Lozano Cutanda, B., "Régimen sancionador”, obra citada, pp. 909-920. 
La segunda fase es la de instrucción del procedimiento sancionador, cuyo objeto comprobar los hechos y otras circunstancias del caso, garantizando la legalidad y la oportunidad del mismo. Fase especialmente importante en cualquier procedimiento sancionador y especialmente en los relativos a los bienes públicos, al tener que realizarse todas las comprobaciones necesarias sobre los hechos, cobrando especial relevancia los inventarios y anotaciones registrales de los mismos, en su caso. Realizadas estas actividades, el instructor redactará la propuesta de resolución del procedimiento, en la que se fijarán motivadamente los hechos, especificando los probados y su calificación jurídica, la valoración de las pruebas, cuando sea la pieza clave de la decisión, la infracción y la persona o personas responsables, con la correspondiente sanción y las medidas provisionales, en su caso, o bien declarará la inexistencia de la infracción o de la responsabilidad; propuesta que ha de ser notificada debidamente a los interesados. Frente a lo anterior, debe abrirse la fase de audiencia al inculpado, en la cual podrá conocer el expediente y formular las alegaciones y presentar los documentos u otra información que estime conveniente. A continuación, el instructor remitirá el expediente al órgano competente para resolverlo. No obstante, tanto la legislación general como la LPAP (art. 193, que prevé el caso de corrección por el infractor de la situación generada por la infracción) permite que el procedimiento sancionador termine de forma anticipada, si el inculpado reconoce voluntariamente su responsabilidad en los hechos.

Realizadas las actuaciones anteriores, el órgano competente dictará la resolución que pone fin al procedimiento sancionador, que debe ser motivada y decidir sobre todas las cuestiones planteadas por los interesados y las derivadas del propio procedimiento.

Por otra parte, en el supuesto de que el órgano competente considere que hay suficientes elementos de juicio para calificar la infracción como leve, la legislación general prevé un procedimiento sancionador simplificado.

\section{El problema del carácter de la extinción de las autorizaciones y concesiones demaniales}

\section{A) Aspectos generales sobre el uso de los bienes demaniales, las autorizaciones y las concesiones}

Los bienes de dominio público tienen como característica más destacable su afectación al uso general o al servicio público ${ }^{77}$, permitiendo así ser la base del funcio-

77 En relación con el uso de los bienes públicos, y especialmente los demaniales, ver en general De Rivera García de Leániz, “Utilización de los bienes y derechos de dominio público”, en De Fuentes Bardajía, J. (Dir.), y otros-Abogacía General del Estado (Dirección General del Servicio Jurídico del Estado), 490 “ "Comentarios a la Ley de Patrimonio de las Administraciones Públicas”, Ed. Abogacía General del Estado 
namiento de las Administraciones Públicas y gozar los ciudadanos de determinados bienes y servicios, de forma general o no, según los casos. El uso de estos bienes es su situación normal, pues es su finalidad; pero este uso ha de hacerse de tal manera que permita el mismo, sin deterioro, para que a lo largo del tiempo su finalidad puede continuar prestándose, ya sea como base de las funciones administrativas o para uso ciudadano.

La forma de alcanzar los fines de los bienes demaniales, incluyendo el uso por los ciudadanos, es exigir un título habilitante, otorgado por la autoridad competente, para ocuparlos o utilizarlos en forma que exceda el derecho de uso que, en su caso, corresponda a todos; siendo la vigilancia de lo establecido función destacable de los órganos responsables de la tutela y defensa del dominio público, que deben actuar contra quienes, careciendo del título correspondiente, ocupen estos bienes o se beneficien de su aprovechamiento, ejercitando las facultades del art. 41 , ya vistas. De acuerdo con el modelo normativo ya visto, el régimen de estos títulos habilitantes, autorizaciones y concesiones, del uso de los bienes demaniales se rige en primer término por la legislación especial reguladora de estas y supletoriamente por las disposiciones de la LPAP (art. 84).

En relación con los bienes demaniales destinados al uso general, en primer término pueden destinarse a uso común, que corresponde por igual y de forma indistinta a todos los ciudadanos, de tal modo que el uso por unos no impide el de los demás interesados, y el cual puede realizarse libremente, sin más limitaciones que las derivadas de su naturaleza, lo establecido en la afectación o adscripción y las disposiciones aplicables. En segundo lugar, estos bienes pueden tener un aprovechamiento especial, que, sin impedir el uso común, supone la existencia de ciertas circunstancias (como peligrosidad, intensidad de uso, preferencia en casos de escasez, obtención de rentabilidad singular u otras semejantes), que determinan un exceso de utilización sobre el uso que corresponde a todos o un menoscabo de éste; estando sujeto a autorización si la ocupación se produce únicamente con instalaciones desmontables o bienes muebles, o si el aprovechamiento es inferior a cuatro años. Finalmente, el uso privativo implica la ocupación de los bienes de modo que se limita o excluye su utilización por otros interesados; exigiéndose la concesión demonial si la ocupación es

\footnotetext{
de los bienes y derechos públicos: estudio de su régimen jurídico", en Mestre Delgado, J. F. (Dir.), y otros, "El Régimen Jurídico del Patrimonio de las Administraciones Públicas (Comentario a la Ley 33/2003, de 3 de noviembre)”, Ed. El Consultor, Madrid, 2004, pp. 815-978; González García, J. V., “Notas sobre el régimen general del dominio público", en González García, J. V. (Dir.), y otros, “Derecho de los Bienes Públicos”, 2. ${ }^{a}$ ed. Ed. Tirant Lo Blanch, Valencia 2009, pp. 96-108; Herranz Embid, P., "Utilización de los Bienes del Dominio Público: Planteamiento general”, en González García, J. V. (Dir.), y otros, “Diccionario de Obras Públicas y Bienes Públicos”, Ed. Iustel, Madrid, 2007, pp. 749-760; Moreu Carbonell, E., “El Derecho Público de los Bienes", en Bermejo Vera, J. (Dir.), y otros, "Derecho Administrativo. Parte Especial”, $6 .{ }^{a}$ ed., Ed. Thomson-Civitas, Cizur Menor (Navarra), 2005, pp. 371-377; Parejo Alfonso, L., "El régimen de la utilización de los bienes y derechos de dominio público. Autorizaciones y concesiones”, en Chinchilla Marín, C. (Coord.), y otros, "Comentarios a la Ley 33/2003, del Patrimonio de las Administraciones Públicas", obra citada, pp. 433-474, y Santamaría Pastor, J. A., "Principios de Derecho Administrativo General”, obra citada, pp. 563-576.
} 
con instalaciones desmontables o bienes muebles por plazo superior a cuatro años o con obras o instalaciones fijas (arts. 85 y 86-LPAP).

Además, la LPAP regula el régimen de utilización de los bienes y derechos destinados a un servicio público, reglados o no y edificios administrativos, remitiendo su uso a la normativa aplicable, a los actos de afectación o adscripción y permitiendo excepcionalmente la ocupación de los edificios administrativos, exigiéndose en este caso también autorizaciones o concesiones; previéndose finalmente autorizaciones especiales para el uso de bienes del Patrimonio del Estado (arts. 85-90).

El régimen jurídico de las autorizaciones y las concesiones ${ }^{78}$ se establece con detalle en los arts. 91-103-LPAP, siendo diferente el de unas y otras. Así, las autorizaciones se otorgan directamente al solicitante, salvo que el número esté limitado, en que se otorgan mediante concurrencia o sorteo, según los casos, exigiéndose una garantía para responder a posibles daños, y las concesiones deben otorgarse en concurrencia competitiva, salvo si el solicitante es una Administración Pública, una entidad sin ánimo de lucro o una confesión religiosa, y aplicándose las prohibiciones para contratar establecidas en la legislación de contratación pública. En ambos casos deben formalizarse en documento administrativo los títulos habilitantes correspondientes, con el contenido establecido en la Ley, que en el caso de las concesiones será suficiente para inscribirlas en el Registro de la Propiedad. La trasmisión de las autorizaciones es posible, con ciertas limitaciones, y en el supuesto de las concesiones se admite, aunque no con claridad. La duración de unas y otras es un elemento diferenciador, pues las autorizaciones no pueden superar cuatro años, incluyendo las prórrogas, y las concesiones no pueden superar los setenta y cinco años, con las prórrogas también incluidas. Asimismo, ambas se diferencia en relación a su revocabilidad, pues las primeras lo pueden ser unilateralmente en cualquier momento sin indemnización alguna, en determinados casos, y las concesiones lo pueden ser mediante rescate pero con indemnización al concesionario. Por último, ambas pueden tener una contraprestación, si bien es gratuita cuando no lleve aparejada una utilidad económica para la persona autorizada o ésta sea despreciable.

78 En relación con el régimen de las autorizaciones y concesiones pueden verse en Fernández Acevedo, R., "Las concesiones administrativas de dominio público", Ed. Thomson-Civitas, Madrid, 2007, y "Utilización de los bienes y derechos públicos: estudio de su régimen jurídico”, en Mestre Delgado, J. F. (Dir.), y otros, “El Régimen Jurídico del Patrimonio de las Administraciones Públicas (Comentario a la Ley 33/2003, de 3 de noviembre)", obra citada, pp. 898-967; González García, J. V., "Notas sobre el régimen general del dominio público”, en González García, J. V. (Dir.), y otros, “Derecho de los Bienes Públicos”, obra citada, pp. 103-108; García Pérez, M., “Autorización y concesión demonial”, en González García, J. V. (Dir.), y otros, “Diccionario de Obras Públicas y Bienes Públicos”, obra citada, pp. 83-92; Moreu Carbonell, E., "El Derecho Público de los Bienes", en Bermejo Vera, J. (Dir.), y otros, "Derecho Administrativo. Parte Especial”, obra citada, pp. 371-377; Ordíz Fuertes, M. ${ }^{a}$ C., "Autorizaciones y concesiones demaniales", en De Fuentes Bardajía, J. (Dir.), y otros-Abogacía General del Estado (Dirección General del Servicio Jurídico del Estado), “Comentarios a la Ley de Patrimonio de las Administraciones Públicas”, obra citada, pp. 729784; Parejo Alfonso, L., “El régimen de la utilización de los bienes y derechos de dominio público. Autorizaciones y concesiones”, en Chinchilla Marín, C. (Coord.), y otros, “Comentarios a la Ley 33/2003, del Patrimo492 Dio de las Administraciones Públicas", obra citada, pp. 433-474, y Santamaría Pastor, J. A., "Principios de 


\section{B) La naturaleza de la extinción de las autorizaciones y concesiones demaniales}

La finalidad de los bienes públicos (servir de base para que la Administración Pública desarrolle sus funciones y permitir a los ciudadanos utilizar determinados bienes y acceder a las prestaciones de los servicios públicos), así como la imprescriptibilidad de los de dominio público, justifican que tanto las autorizaciones de uso como las concesiones demaniales deban extinguirse, así como los derechos de ocupación y uso correspondientes que conllevan.

Dada la importancia de tal cuestión en el régimen de los bienes demaniales, la LPAP, con el carácter de normativa básica (ex DF-2. ${ }^{a}$ ), establece las causas de extinción de las autorizaciones y concesiones ${ }^{79}$ en su art. 100, que incluye, entre otras (ya que se prevé una cláusula abierta a otras causas fijadas en las condiciones generales o particulares por las que se rijan, ex letra i), las relativas a muerte o incapacidad sobrevenida del usuario o concesionario individual o extinción de la personalidad jurídica; falta de autorización previa en los casos de transmisión o modificación, por fusión, absorción o escisión, de la personalidad jurídica del usuario o concesionario; caducidad por vencimiento del plazo; rescate de la concesión, previa indemnización, o revocación unilateral de la autorización; mutuo acuerdo; desaparición del bien o agotamiento de su aprovechamiento, y desafectación del bien.

Además, también se incluye como causa de extinción de las autorizaciones y concesiones demaniales la falta de pago del canon o cualquier otro incumplimiento grave de las obligaciones del titular de la concesión, declarados por el órgano que otorga unas u otras (art. 100, f), que deriva del hecho de que para ambas es obligatorio incluir, en sus condiciones, el régimen de uso del bien o derecho (arts. 92-7..$^{\circ}$ a, y 93-5LPAP). Extinción que exige que el incumplimiento no sea de cualquier entidad sino que ha de ser grave y que el mismo se declare como tal por el órgano competente.

El problema ${ }^{80}$ que se plantea en relación a estos supuestos es el de la naturaleza de la potestad a ejercitarse, y el régimen jurídico consiguiente que haya de aplicarse; surgiendo dos posiciones, una que mantiene que no estamos ante una potestad sancionadora, pues lo único que se pretende es evitar perjuicios al interés general deriva-

79 En relación con la extinción de las autorizaciones y concesiones ver Fernández Acevedo, R., “Utilización de los bienes y derechos públicos: estudio de su régimen jurídico”, en Mestre Delgado, J. F. (Dir.), y otros, “El Régimen Jurídico del Patrimonio de las Administraciones Públicas (Comentario a la Ley

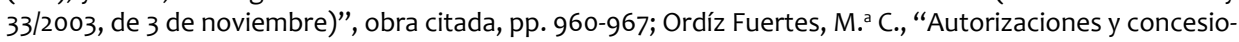
nes demaniales", en De Fuentes Bardajía, J. (Dir.), y otros-Abogacía General del Estado (Dirección General del Servicio Jurídico del Estado), "Comentarios a la Ley de Patrimonio de las Administraciones Públicas", obra citada, pp. 761-772, y Mestre Delgado, J. F., “La extinción de las autorizaciones y concesiones demaniales”, en Chinchilla Marín, C. (Coord.), y otros, “Comentarios a la Ley 33/2003, del Patrimonio de las Administraciones Públicas”, obra citada, pp. 491-520.

80 Sobre el planteamiento del problema, ver Quintana López, T., “Viejos y nuevos problemas de la concesión minera”, Revista Jurídica de Castilla y León, n. $18 / 2009$, pp. 13-73, en especial pp. 57 y ss.; a quien seguimos. También Ordíz Fuertes, M. ${ }^{a}$ C., “Autorizaciones y concesiones demaniales”, obra citada, pp. 769 y 770 . 
dos del uso y aprovechamiento inadecuados de los bienes demaniales por el titular correspondiente, debiendo por tanto aplicarse la normativa específica y utilizarse el procedimiento administrativo ordinario para declarar la extinción de la misma, y otra posición que defiende que estaríamos ante el ejercicio de la potestad sancionadora por hacer referencia a incumplimientos del concesionario, debiendo aplicarse la normativa correspondiente y utilizarse el procedimiento administrativo sancionador (mucho más rígido y protector) para proceder a la extinción de la concesión.

Ciertamente, en el pasado algunas Leyes prescribieron que no suponía el ejercicio de la potestad sancionadora, como el art. 158 de la Ley de Aguas de 13 de junio de 1879 (Gaceta del 19), que preveía la caducidad de las concesiones de aprovechamientos de aguas en caso de no haberse cumplido las condiciones de otorgamiento, o como, con más claridad, reflejaba el art. 121, en su redacción original, de la Ley 22/1973, de 21 de julio, de Minas (BOE del 24), al establecer una sanción determinada a "la infracción de los preceptos de esta Ley y de su Reglamento que no dé lugar a declaración de caducidad", de acuerdo con lo previsto en la misma; disposición que se reproducía en el art. 80 de la Ley 21/1974, de 27 de junio de Investigación y Explotación de Hidrocarburos (BOE del 29). Por su parte, la Ley del Patrimonio del Estado de 1964, únicamente hablaba de declaración de caducidad de las concesiones (art. 127), si referencia alguna a la potestad sancionadora.

La no consideración de la extinción de las concesiones como derivación de la potestad sancionadora ${ }^{81}$ se asumió claramente en la STS de 18 de julio de 1994 (AR. 5850), al señalar que "el incumplimiento de las condiciones impuestas en las concesiones de aprovechamientos privativos de aguas públicas, pueden dar lugar a una doble consecuencia perjudicial para el concesionario, bien de tipo puramente sancionador o bien de características revocatorias o de caducidad de la concesión"; estimando en el caso de autos, un recurso contra un cierre de compuertas, que estamos ante el aspecto revocatorio de la concesión, por lo que no admite la necesidad de aplicar las garantías del ámbito sancionador.

En la actualidad, debe señalarse que el art. 192-2.., e-LPAP, establece como infracción grave "el uso de bienes de dominio público objeto de concesión o autorización sin sujetarse a su contenido o para fines distintos de los que las motivaron”; en

81 Quintana López, T., “Viejos y nuevos problemas de la concesión minera”, obra citada, pp. 6263, estima que “en definitiva, pues, el redactor del artículo 121 de la LMi, dándole una nueva dicción [la de la reforma de 2007], se ha decantado por no considerar a la declaración de caducidad como expresión de la potestad sancionadora de la Administración, que es lo técnicamente correcto". Asimismo, Ordíz Fuer-

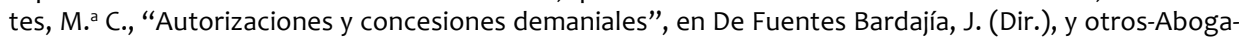
cía General del Estado (Dirección General del Servicio Jurídico del Estado), “Comentarios a la Ley de Patrimonio de las Administraciones Públicas”, obra citada, pp. 769-770, y Mestre Delgado, J. F., "La extinción de las autorizaciones y concesiones demaniales", en Chinchilla Marín, C. (Coord.), y otros, "Comentarios a la Ley 33/2003, del Patrimonio de las Administraciones Públicas”, obra citada, pp. 505-506, mantienen 494 claramente que la extinción por incumplimiento no tiene carácter sancionador, citando ambos la misma 
cuyo caso, y cumpliendo los requisitos del mismo, debe aplicarse e iniciarse el procedimiento sancionador; no haciéndose referencia a la extinción de las concesiones.

En relación con la legislación sectorial de los bienes concretos actualmente vigente, la mayoría de los textos desvinculan la extinción de la concesión de la potestad sancionadora, previendo ambas opciones. Así, el Texto Refundido de la Ley de Aguas (Real Decreto Legislativo 1/2001, de 20 de julio, BOE del 24) al considerar, en su art. 116, como infracción el incumplimiento de las condiciones impuestas en las concesiones y autorizaciones administrativas a que se refiere la Ley, "sin perjuicio de su caducidad, revocación o suspensión”, previéndose además que "las concesiones podrán declararse caducadas por incumplimiento de cualquiera de condiciones esenciales" (art. 66).

En parecido sentido se expresa la Ley 22/1988, de 28 de julio, de Costas (BOE del 29), al prever la caducidad de las concesiones por incumplimiento de las condiciones establecidas (art. 79) y asimismo considerar una infracción "el incumplimiento de las condiciones correspondientes títulos administrativos, sin perjuicio de su caducidad" (art. 90, d).

Por su parte, y en la misma línea, el art. 121 de la Ley de Minas, según redacción de 2007, prevé la sanción de "las infracciones a los preceptos de esta Ley, sin perjuicio de la declaración de caducidad o suspensión de los trabajos cuando ello proceda"82.

Por otra parte, la Ley 27/1992, de 24 de noviembre, de Puertos del Estado y de la Marina Mercante (BOE del 25), incluye como infracciones leves (art. 114-2. ${ }^{\circ}$ ), en lo que se refiere a actividades sujetas a previa autorización, concesión o prestadas mediante contrato, la relativa al "incumplimiento de las condiciones de los correspondientes títulos administrativos de las cláusulas de los contratos de prestación indirecta de los servicios portuarios o de los pliegos de condiciones generales que los regulen, sin perjuicio de su caducidad o rescisión", pero teniendo en cuenta que el régimen de las concesiones se regula en la Ley 48/2003, de 26 de noviembre, de Régimen Económico y de Prestación de Servicios de los Puertos de Interés General (BOE del 27), la cual establece en su art. 123 como causas de caducidad de la autorización o concesión, entre otras, el impago de una liquidación por cualquiera de las tasas giradas por la Autoridad Portuaria durante un plazo de seis meses, en el caso de las autorizaciones, y de 12 meses en el caso de las concesiones (letra b), falta de actividad o de prestación del servicio, durante un período de seis meses, en el caso de autorizaciones, y de 12 meses en el caso de las concesiones, a no ser que, a juicio de la Autoridad Portuaria, obedezca a causa justificada (letra c), desarrollo de actividades que no figuren en el

82 Quintana López, T., “Viejos y nuevos problemas de la concesión minera”, obra citada, p. 62, estima que "a nuestro juicio, [el precepto citado] desvincula la declaración de caducidad del título minero del ejercicio de la potestad sancionadora, pues a la vista del artículo 121 de la LMi, son infracciones los hechos tipificados como tales por dicho precepto, sin perjuicio de que, desde otra perspectiva, eventualmente alguno de esos hechos, y también otros, puedan determinar la caducidad del título concesional." 
objeto del título (letra f), transferencia del título de otorgamiento, sin autorización de la Autoridad Portuaria (letra h), no reposición o complemento de las garantías definitiva o de explotación, previo requerimiento de la Autoridad Portuaria (letra j), e incumplimiento de otras condiciones cuya inobservancia esté expresamente prevista como causa de caducidad en el título de otorgamiento (letra k); no previendo referencias a la potestad sancionadora (que se prevén en la otra Ley).

Asimismo, la Ley 34/1998, de 7 de octubre, del Sector de Hidrocarburos (BOE del 8), únicamente prevé la extinción de autorizaciones y concesiones por incumplimiento de las condiciones de su otorgamiento (art. 34), sin referencia alguna a la potestad sancionadora.

Sin embargo, la Ley 3/1995, de 23 de marzo, de Vías Pecuarias (BOE del 24), incluye como infracción el incumplimiento de las condiciones establecidas en los correspondientes títulos administrativos; en referencia a los que habilitan la ocupación de las mismas (arts. 14 y 21). 